\title{
UV-C Peroxymonosulfate Activation for Wastewater Regeneration: Simultaneous Inactivation of Pathogens and Degradation of Contaminants of Emerging Concern
}

\author{
Ilaria Berruti ${ }^{1}$, Samira Nahim-Granados ${ }^{1,2}$, María Jesús Abeledo-Lameiro ${ }^{1}$, Isabel Oller ${ }^{1,2}$ \\ and María Inmaculada Polo-López ${ }^{1,2, *}$ \\ 1 CIEMAT-Plataforma Solar de Almería, Carretera de Senés Km 4, 04200 Tabernas, Almería, Spain; \\ iberruti@psa.es (I.B.); snahim@psa.es (S.N.-G.); mabeledo@psa.es (M.J.A.-L.); ioller@psa.es (I.O.) \\ 2 CIESOL, Joint Centre of the University of Almería-CIEMAT, 04120 La Cañada, Almería, Spain \\ * Correspondence: mpolo@psa.es; Tel.: +34-950-387900
}

Citation: Berruti, I.;

Nahim-Granados, S.;

Abeledo-Lameiro, M.J.; Oller, I.;

Polo-López, M.I. UV-C

Peroxymonosulfate Activation for

Wastewater Regeneration:

Simultaneous Inactivation of

Pathogens and Degradation of

Contaminants of Emerging Concern. Molecules 2021, 26, 4890. https://

doi.org/10.3390/molecules26164890

Academic Editors: Marcelo

I. Guzman, Davide Vione and

James Barker

Received: 14 July 2021

Accepted: 8 August 2021

Published: 12 August 2021

Publisher's Note: MDPI stays neutral with regard to jurisdictional claims in published maps and institutional affiliations.

Copyright: (c) 2021 by the authors. Licensee MDPI, Basel, Switzerland. This article is an open access article distributed under the terms and conditions of the Creative Commons Attribution (CC BY) license (https:// creativecommons.org/licenses/by/ $4.0 /)$.

\begin{abstract}
This study explores the capability of Sulfate Radical-based Advanced Oxidation Processes (SR-AOPs) for the simultaneous disinfection and decontamination of urban wastewater. Sulfate and hydroxyl radicals in solution were generated activating peroxymonosulfate (PMS) under UV$\mathrm{C}$ irradiation at pilot plant scale. The efficiency of the process was assessed toward the removal of three CECs (Trimethoprim (TMP), Sulfamethoxazole (SMX), and Diclofenac (DCF)) and three bacteria (Escherichia coli, Enterococcus spp., and Pseudomonas spp.) in actual urban wastewater (UWW), obtaining the optimal value of PMS at $0.5 \mathrm{mmol} / \mathrm{L}$. Under such experimental conditions, bacterial concentration $\leq 10 \mathrm{CFU} / 100 \mathrm{~mL}$ was reached after $15 \mathrm{~min}$ of UV-C treatment $(0.03 \mathrm{~kJ} / \mathrm{L}$ of accumulative UV-C radiation) for natural occurring bacteria, no bacterial regrowth was observed after 24 and $48 \mathrm{~h}$, and 80\% removal of total CECs was achieved after $12 \mathrm{~min}(0.03 \mathrm{~kJ} / \mathrm{L})$, with a release of sulfate ions far from the limit established in wastewater discharge. Moreover, the inactivation of Ampicillin (AMP), Ciprofloxacin (CPX), and Trimethoprim (TMP) antibiotic-resistant bacteria (ARB) and reduction of target genes (ARGs) were successfully achieved. Finally, a harmful effect toward the receiving aquatic environment was not observed according to Aliivibrio fischeri toxicity tests, while a slightly toxic effect toward plant growth (phytotoxicity tests) was detected. As a conclusion, a cost analysis demonstrated that the process could be feasible and a promising alternative to successfully address wastewater reuse challenges.
\end{abstract}

Keywords: peroxymonosulfate/UV-C; wastewater reclamation; bacteria; contaminants of emerging concern; toxicity

\section{Introduction}

Nowadays, water scarcity has become a critical issue, and the reuse of reclaimed urban wastewater (UWW) has become a reliable alternative source to address this problem. This practice could have social and economic benefits, enhancing water balance, alleviating the actual stress conditions, and promoting circular economy [1]. To promote the safe water reuse, different challenges need to be successfully addressed, including the addition of an efficient tertiary treatment step in Urban Wastewater Treatment Plants (UWWTPs) to meet water quality limits. The European commission approved in 2020 a regulation on "minimum requirements for water reuse in agricultural irrigation and aquifer recharge" in order to assure the microbiological safety of treated UWW [2]. This regulation includes microbial assessment, of which $E$. coli is the main indicator. However, other pollutants, such as Contaminants of Emerging Concern (CECs) and Antibiotic Resistance Bacteria and Genes (ARB and ARGs), are not yet inserted in the regulation as criteria, but their presence is of concern from the human and environmental health point of view. Therefore, 
their removal should be investigated for the future implementation of new technologies, reaching a safety UWW reuse [3].

CECs are organic substances that have been detected at low levels in the environment (from ng/L to $\mu \mathrm{g} / \mathrm{L}$ ) and have the potential to cause an adverse impact on human health and the environment [4]. They include surfactants, flame retardants, pharmaceuticals and personal care products, gasoline additives, pesticides, and endocrine-disrupting compounds (EDCs). Their release into the environment is mainly associated to the continuous discharge of UWW effluents, as they are inefficiently removed by conventional UWWTPs treatments [3]. An additional concern is related to their uptake by crops and accumulation in soil during irrigation with reclaimed water [5]. Moreover, the co-presence of antibiotics, bacteria, and a nutrients-rich environment in UWWTPs promotes the development and the proliferation of ARB and ARGs, posing an additional health risk [6]. It is recognized that ARB infections have higher mortality, and they are estimated to cause 10 million deaths worldwide by year 2050, according to the World Health Organization [7].

Therefore, the upgrade of UWWTPs is required to reach a safer reclaimed water, achieving in addition to the parameters already included in regulations, good CECs, $\mathrm{ARB}$, and ARGs removal performances [8]. The most used tertiary treatment involves chlorination, which is a low-cost method for UWW disinfection, but it is poorly effective in CECs removal and ARGs control, being the main concern of its application related to Disinfection By-Products (DBPs) formation. Ozonation provides good performances for bacteria inactivation and CECs degradation, but the high cost and the generation of brominated DBPs constitute the main drawbacks of this treatment [3]. UV-C is generally recognized as an effective tool for inactivating microorganisms in water, but it is not able to guarantee water safety during storage, due to DNA repair mechanisms and the eventual bacterial regrowth [9].

Consequently, research on highly efficient treatments for both water disinfection and decontamination has been raised in the last decades, including the so-called Advanced Oxidation Processes (AOPs), whose successful results rely on the potential generation of Reactive Oxygen Species (ROS), mainly hydroxyl radicals $\left({ }^{\bullet} \mathrm{OH}\right)$. Nevertheless, sulfate radical $\left(\mathrm{SO}_{4}{ }^{\bullet-}\right)$-based advanced oxidation processes (SR-AOPs) are gaining attention as promising treatment technologies due to their potential to inactivate a wide range of pathogens and to degrade CECs in different water matrices such as domestic or industrial WW $[10,11] . \mathrm{SO}_{4}^{\bullet-}$ mainly reacts by electron transfer reactions as the main oxidation mechanism, exhibiting longer half-life, higher redox potential, and higher selectivity than - $\mathrm{OH}$. Moreover, it is consumed by the main water matrix constituents with lower kinetic rates [12].

In SR-AOPs, ROS are generated in solution by the activation of persulfate (PS) or peroxymonosulfate (PMS) by different methods, such as UV-C radiation, transition metals, heat, and alkaline conditions [12,13]. Among these methods, UV-C radiation is one of the most investigated due to its high efficiency supplying the energy needed to cleavage the $\mathrm{O}-\mathrm{O}$ bond of PMS molecules and generating both, $\mathrm{SO}_{4}{ }^{\bullet-}$ and ${ }^{\bullet} \mathrm{OH}$.

SR-AOPs based on UV-C radiation have been experimentally proved as efficient in the removal of different CECs using low oxidant dosages (PMS and PS at 0.05-0.5 mmol/L) at very low contact times (4-18 s) [14]. However, the simultaneous disinfection and decontamination of secondary WWTP effluents via SR-AOPs has been poorly investigated [15], with limited information on the process capability to address the problem of ARB and ARGs removal.

Thus, the main goal of this study is the evaluation of PMS/UV-C process performance toward different criteria, such as CECs, bacteria, and antibiotic-resistant targets (ARB and ARGs) removal, toxicity, and costs, to address the urban wastewater reuse challenge and assuring the safe use of reclaimed water. The inactivation of several microbial targets (E. coli, Enterococcus spp., and Pseudomonas spp.) and the degradation of three CECs (Diclofenac (DCF), Sulfamethoxazole (SMX), and Trimethoprim (TMP)) were assessed in simulated and actual secondary effluent from urban wastewater (SUWW and UWW) at 
pilot plant scale. Then, the occurrence of naturally occurring multidrug (namely ampicillin (AMP), ciprofloxacin (CPX), and trimethoprim (TMP)) resistant E. coli, Enterococcus spp., and Pseudomonas spp. strains and ARGs in UWW was probed, and their removal was investigated. Moreover, a possible toxic effect of residual PMS was evaluated toward Aliivibrio fischeri luminescent bacteria (evaluating a possible damage to the receiving aquatic environment after treated effluent discharge) and toward the germination of three seeds, such as Sorghum saccharatum, Lepidium sativum, and Sinapis alba (evaluating phytotoxicity after irrigation with reclaimed UWW). Finally, an economic analysis of the treatment was performed to assess process feasibility.

\section{Materials and Methods}

\subsection{Water Matrices}

Two water matrices were used in this study: (i) Simulated Urban Wastewater (SUWW) and (ii) Actual Urban Wastewater (UWW). SUWW was prepared following a recipe previously reported [16] as a UWW effluent model to guarantee the reproducibility and comparability of results among the different operational conditions. UWW was freshly collected from the effluent of the secondary treatment (conventional activated sludge) of the urban wastewater treatment plant of "El Bobar", which is located in Almeria, South East of Spain, and several batches were used along the experimental plan. The physicochemical and microbiological characterization of both water matrices are summarized in Table S1 (Supplementary Material).

Physicochemical characterization was done by using a $\mathrm{pH}$ meter (multi720, WTW, Weilheim, Germany), conductivity meter (GLP31, CRISON, Barcelona, Spain), turbidimeter (Model 2100N, Hach, Colorado, USA), ion chromatograph (Model 850, Metrohm, Herisau, Switzerland in a column METROSEP C4-250/4.0 (250 mm $\times 4.0 \mathrm{~mm}$ ID)), and Total Organic Carbon (TOC) analyzer (Model 5050, Shimadzu, Kyoto, Japan). The microbiological characterization of UWW was performed following the methodologies described in Section 2.3.

\subsection{Contaminants of Emerging Concern Quantification}

Three common pharmaceutical substances frequently detected in secondary effluents of UWW were used in this study: Trimethoprim (TMP), Diclofenac (DCF), and Sulfamethoxazole (SMX). They were purchased from Sigma-Aldrich with high purity grade ( $>99 \%)$. The initial concentration of each CEC was $100 \mu \mathrm{g} / \mathrm{L}$, which was obtained by directly diluting a concentrated stock solution of each compound in both water matrices. The CECs quantification was performed by UPLC/UV (Agilent Technologies, Series 1260), following the working conditions described elsewhere [17] to simultaneously detect the three CECs. The limit of quantification (LOQ) was 8, 8, and $20 \mu \mathrm{g} / \mathrm{L}$ for DCF, SMX, and TMP, respectively. The treatment efficiency for CECs removal is established according to $80 \%$ removal, value in agreement with the Swiss Water Protection Act, which is the only regulation at the European Level that establishes in Switzerland the requirement of monitoring and removing selected CECs in UWWTPs [18].

\subsection{Bacteria and ARB Enumeration}

E. coli O157:H7 (CECT 4972), E. faecalis (CECT 5143), and P. aeruginosa (CECT 110) provided by the Spanish Culture Collection (CECT) were used as microbial targets in SUWW assays. For this aim, liquid cultures were daily prepared by bacteria incubation at $37^{\circ} \mathrm{C}$ and $100 \mathrm{rpm}$ (rotary shaking) for $20 \mathrm{~h}$ (stationary concentration of $\approx 10^{9} \mathrm{CFU} / \mathrm{mL}$ ) in the specific liquid broth medium for each bacteria according to CECT instructions. Bacterial suspensions obtained were centrifuged ( $3000 \mathrm{rpm}, 15 \mathrm{~min}$ ), re-suspended in phosphatebuffered saline (PBS) solution, and directly spiked in the reactors to achieve the desired initial concentration $\left(10^{6} \mathrm{CFU} / \mathrm{mL}\right.$ ). In actual UWW, naturally occurring bacteria (E. coli, Enterococcus spp., Pseudomonas spp., and Total coliforms) (occurrence in UWW is shown in Table S1) and AR-bacteria (E. coli, Enterococcus spp., and Pseudomonas spp.) were monitored. 
Water samples from experiments were serially diluted in PBS and enumerated using the standard plate counting method by spreading sample volumes from 50 to $500 \mu \mathrm{L}$ in selective and specific agar media and its subsequent incubation: ChromoCult Coliform Agar (Merck KGaA, Darmstadt, Germany) $24 \mathrm{~h}$ at $37{ }^{\circ} \mathrm{C}$, P. aeruginosa agar (Conda, Pronadisa, Madrid, Spain) $48 \mathrm{~h}$ at $35^{\circ} \mathrm{C}$, and Slanetz Bartley agar (Scharlau, Barcelona, Spain) $48 \mathrm{~h}$ at $37^{\circ} \mathrm{C}$ for E. coli, Pseudomonas spp., and Enterococcus spp., respectively. When lower concentrations than $10 \mathrm{CFU} / \mathrm{mL}$ were expected, the membrane filtration method was also used to attain a detection limit (DL) of $1 \mathrm{CFU} / 100 \mathrm{~mL}$ to fit with the limits established in wastewater reuse guidelines. Then, $100 \mathrm{~mL}$ of sample was filtered using a Microfil ${ }^{\circledR}$ filtration system (Millipore, Burlington, MA, USA) and cellulose nitrate filters ( $0.45 \mu \mathrm{m}$, Sartorius Stedim, Göttingen, Germany), using similar culture media procedure as described previously.

In addition, ARB were monitored in UWW following the same procedure described above with selective agar media supplemented with three antibiotics according to the respective minimum inhibitory concentration values available in the EUCAST database. Ampicillin $(8 \mathrm{mg} / \mathrm{L})$, ciprofloxacin $(0.5 \mathrm{mg} / \mathrm{L})$, and trimethoprim $(4 \mathrm{mg} / \mathrm{L})$ for $E$. coli and Pseudomonas spp.; and ampicillin $(8 \mathrm{mg} / \mathrm{L})$, ciprofloxacin $(4 \mathrm{mg} / \mathrm{L})$ and trimethoprim (1 mg/L) for Enterococcus spp.

\subsection{Antibiotic-Resistant Genes (ARGs) Detection and Quantification}

The $16 S$ rRNA gene and several ARGs were quantified using real-time quantitative PCR (qPCR). ARGs included genes encoding resistance to quinolone antibiotic classes $(q n r S)$, sulphonamides (sul1), $\beta$-lactams $\left(b l a_{T E M}\right)$, cephalosporins $\left(b l a_{C T X-M 32}\right)$, tetracycline (tet $M)$, and class 1 integron integrase (intI1), and they were selected due to their occurrence in UWWTPs [8].

UWW samples from El Bobar, UV-C alone test, and PMS/UV-C test at $1 \mathrm{mmol} / \mathrm{L}$ were collected and analyzed. A volume of $100 \mathrm{~mL}$ of each sample was filtered in duplicated through a $0.2 \mu \mathrm{m}$ polycarbonate membrane (CHMLAB GROUP S.L., Barcelona, Spain). Total DNA was extracted from the filtering membrane with the DNeasy ${ }^{\circledR}$ PowerWater ${ }^{\circledR}$ Kit (QIAGEN Sciences Inc., Germantown, USA) according to the manufacturer's indications. The resulting DNA extracts were measured using a NanoDrop ${ }^{\circledR}$ Lite Spectrophotometer (Thermo Scientific, Massachusetts, USA). DNA working solution was stored at $-20{ }^{\circ} \mathrm{C}$ until they were analyzed.

All genes were analyzed in duplicate by q-PCR using a 7500 Fast Real-Time PCR System (Applied Biosystems, Thermo Fisher Scientific Inc., Massachusetts, USA). The working conditions were done by modifications of reported studies in the literature $[19,20]$, and they are presented in Table S2. Amplification data were analyzed calculating the ratio of each analyzed ARG concerning $16 S r R N A$ gene (indicator for the total microbial abundance) using the cycle threshold $(\mathrm{Ct})$ value.

\subsection{UV-C Pilot Plant and Experimental Procedure}

A 80 L UV-C (medium pressure lamp with $254 \mathrm{~nm}$ peak wavelengths, $230 \mathrm{~W}$ ) pilot plant was used in this study in batch mode with a flow-rate of $36 \mathrm{~L} / \mathrm{min}$ and an illuminated volume $\left(\mathrm{V}_{\mathrm{i}}\right)$ of $6.21 \mathrm{~L}$. A full description is reported elsewhere [16]. The UV-C chamber accounts with a UV irradiance detector placed in the inner wall of the lamp chamber to monitor the lamp irradiance $\left(\mathrm{W} / \mathrm{m}^{2}\right)$ emitted at any time. Irradiance profiles observed under UV-C irradiation in SUWW and UWW are reported in Figure S1. This measurement was used to calculate, according to Equation (1), the UV-C accumulative energy per unit of volume $Q_{U V}$ (in kJ/L) [16].

$$
Q_{u V}\left(\frac{k J}{L}\right)=\operatorname{Dose}\left(\frac{k J}{m^{2}}\right) \times A_{i}\left(m^{2}\right) / V_{t}(L)
$$


where Dose is obtained by the UV-C lamp emitted irradiance $\left(\mathrm{W} / \mathrm{m}^{2}\right)$ multiplied by the illumination time fraction (s), $A_{i}$ is the illuminated area $\left(0.34 \mathrm{~m}^{2}\right)$, and $V_{t}$ is the total volume (80 L).

Tests procedure was as follows: (i) fill the reactor with the water matrix (SUWW or UWW) and add CECs and bacteria (only for SUWW) to obtain the desired initial concentrations; (ii) homogenization in dark for $15 \mathrm{~min}$; (iii) addition of PMS and collection of the initial sample (time $0 \mathrm{~min}$ ); (iii) switch-on the UV-C lamp; and (iv) take water samples at regular time intervals for bacterial and CECs quantification. Two replicated experiments of each operational condition were done, and the results of target concentrations detected at any time are presented as the averaged values with their corresponding standard deviation as error.

In addition, water temperature $(\mathrm{T})$ and $\mathrm{pH}$ were monitored along the experimental time with a thermometer (Checktemp, Hanna, Gipuzkoa, Spain) and a pH meter (110-K, Horiba Laqua act, Kyoto, Japan). No significant changes in $\mathrm{T}$ and $\mathrm{pH}$ were observed in any case, remaining constant at values of $28.4 \pm 1.3^{\circ} \mathrm{C}$ and $8.17 \pm 0.04$, respectively. Therefore, PMS thermal activation as well as $\mathrm{pH}$ effect on CECs and bacteria removal could be discarded in our results.

\subsection{Kinetic Analysis}

All bacterial inactivation profiles observed in this study followed a double log-linear kinetic, each one described by Chick-Watson's law. This kinetic inactivation model has been described previously for bacterial inactivation by UV-C lamps, and it is attributed to its highly capability to damage cells observed in a very fast first stage $\left(k_{1}, \mathrm{~min}^{-1}\right)$, followed by a second one $\left(k_{2}, \min ^{-1}\right)$ with lower kinetic constant $\left(k_{1}>>k_{2}\right)$ [13]. CECs degradation obeyed pseudo-first order kinetics $\left(\ln \left(\mathrm{C}_{\mathrm{t}} / \mathrm{C}_{0}\right)=-k \mathrm{t}, \min ^{-1}\right)$.

\subsection{Toxicity Assessment}

The eco-toxicity of samples toward Alivibrio fischeri was assessed following the standard ISO 11348-3 method and using the commercial kit BioFix ${ }^{\circledR}$ Lumi-10 (Macherey-Nagel $\mathrm{GmbH} \&$ Co. KG, Duren, Germany) by monitoring changes in bacteria bioluminescence after $30 \mathrm{~min}$ of contact time [21], and expressed as bioluminescence inhibition percentage (BI \%). Samples were previously filtered $(0.22 \mu \mathrm{m}) ; \mathrm{pH}$ value and salinity were adjusted to $\approx 7$ and $2 \%(w / v)$, respectively. All water samples were analyzed with the PMS contents of $1 \mathrm{mmol} / \mathrm{L}$; therefore, to avoid instant toxic effects of PMS, they were diluted 1:10 $(v / v)$; this dilution factor is below the range of 1:80 to 1:100 v/v usually considered in real UWW coastal discharge [22].

Phytotoxicity tests were performed following standard procedures for root lengths assessment in Sorghum saccharatum (Sorgho), Lepidium sativum (garden cress), and Sinapis alba (mustard), using seeds provided by a commercial kit (Phytotoxkit liquid samples, Microbiotests Inc., Gent, Belgium) [21,23]. A water solution of $\mathrm{Zn}^{2+}(100 \mathrm{mg} / \mathrm{L})$ and fresh-collected UWW were used as positive and negative toxicity control, respectively. Tests were performed by adding $8 \mathrm{~mL}$ of a water sample on Petri dishes $(140 \mathrm{~mm})$ lined with two sterilized filter paper layers $(0.39 \mathrm{~mm}$ thick). A total of 10 seeds (only 5 for $S$. saccharatum) were equally distributed in each Petri dish and incubated for $72 \mathrm{~h}$ in darkness at $25 \pm 1{ }^{\circ} \mathrm{C}$. Then, the radicle lengths were measured to calculate the relative growth index (RGI) as a ratio of radicle length of samples/negative control. Results can be classified as: (i) inhibition (toxic effect) for $0<\mathrm{RGI}<0.8$; (ii) no significant effect for $0.8 \leq \mathrm{RGI} \leq 1.2$; and (iii) stimulation (benefit): RGI $>1.2$ [24].

\section{Results and Discussion}

\subsection{Simultaneous Inactivation of Bacteria and Degradation of CECs in SUWW}

Figure 1 shows the simultaneous inactivation of the sum of all bacteria (Figure 1a) and the degradation of total CECs (Figure 1b) in SUWW by UV-C radiation and PMS/UV-C with concentrations of PMS ranging from 0.01 to $0.5 \mathrm{mmol} / \mathrm{L}$. Tables S3 and S4 report the 
corresponding inactivation and degradation kinetic constants, respectively, and Figure S2 shows individual profiles for each target.

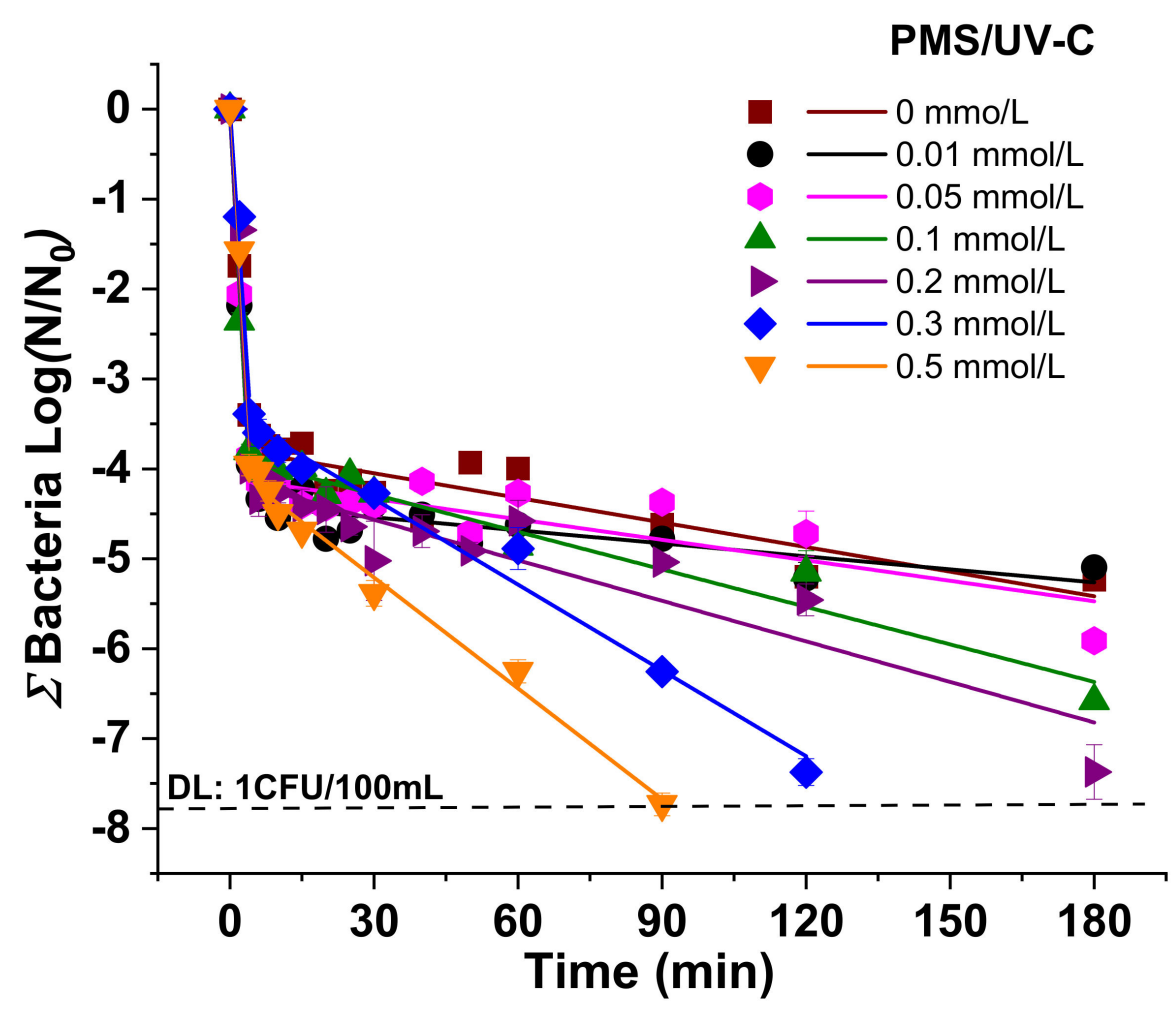

(a)

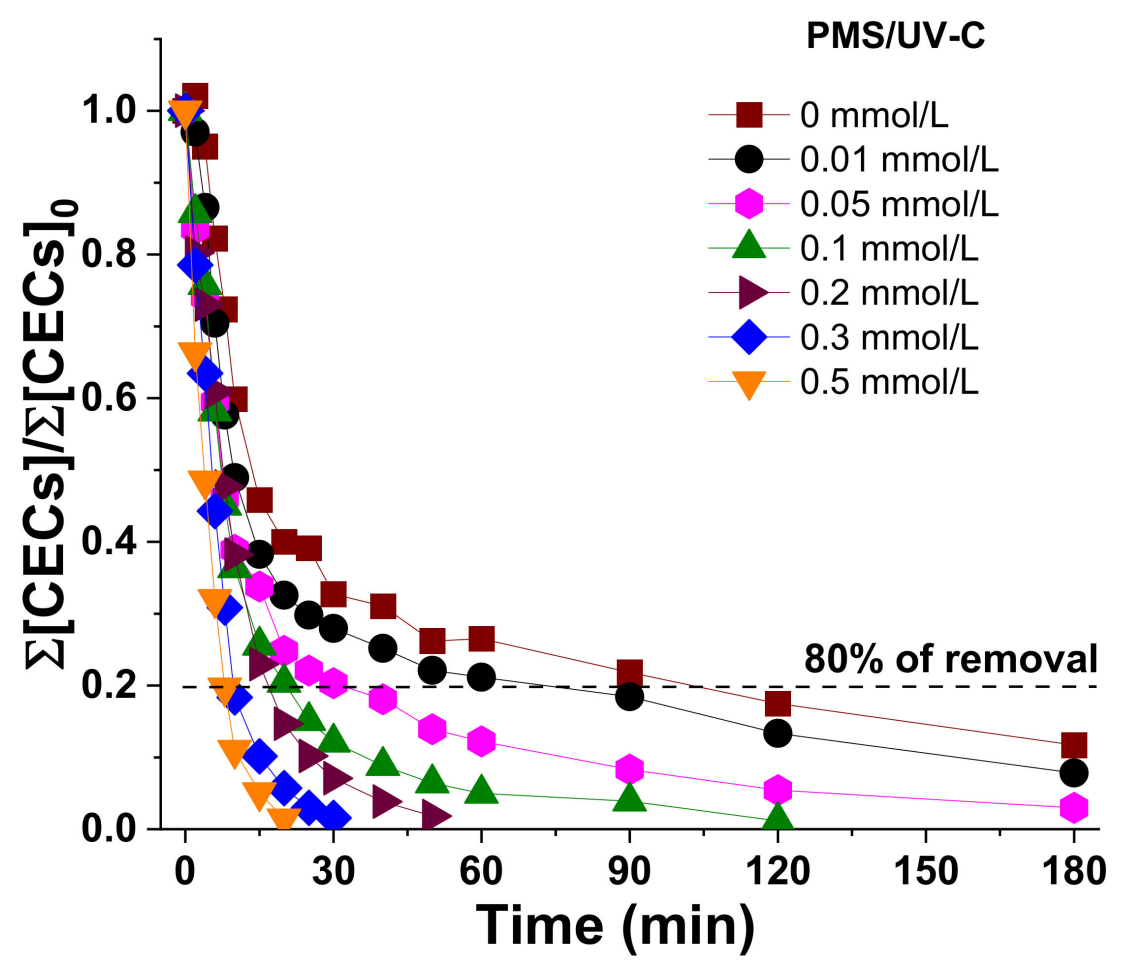

(b)

Figure 1. (a) Linear fitting of total bacteria inactivation; (b) Degradation of total CECs in SUWW under UV-C irradiation in the presence of increasing concentration of PMS (0-0.5 mmol/L). 
The bacterial inactivation profiles observed in all cases obey to a double log-linear kinetic profile explained by the action of the UV-C radiation (a fast $k_{1}$ ) and the experimental setup (slower $k_{2}$ ) (Table S3, Figure S2), which is similar to previous studies using the same UV-C pilot plant [16]. $k_{1}$ is attributed to the well-known efficiency of UV-C wavelengths to inactivate microorganisms in water. As it is observed in our results, no significant differences on the three individual bacterial profile were obtained, attaining 3.4 LRV (Logarithm Reduction Value) in the first $4 \mathrm{~min}$ of treatment time. During this first stage, the inactivation mechanism is attributed to the direct photoabsorption of nucleic acids (maximum absorption at $260 \mathrm{~nm}$ ), with consequent bacterial DNA damages. Upon irradiation, adjacent pyrimidine nucleobases can dimerize, inducing the formation of cyclobutane pyrimidine dimers (CPDs), and the formation of pyrimidine (6-4) pyrimidine dimers [9]. On the other hand, a second kinetic rate $\left(k_{2}\right)$ involving the remaining microbial concentration (up to $4 \mathrm{log}$, considering a detection limit of $1 \mathrm{CFU} / 100 \mathrm{~mL}$ ) clearly showed a process limitation mainly attributed to the flow mode used in this study [16], with very low kinetic rates and not reaching the DL for any of the bacteria investigated. No significant differences between the inactivation profiles of the three bacteria were observed according to $k_{2}$ (Table S3, Figure S2). This result indicates that the reduced efficiency of UV-C process alone to reach the DL could be attributed to the photo-limitation by the configuration of the system (re-circulation flow-mode and low ratio total/illuminated water volume). Consequently, a post-treatment bacterial regrowth analysis after $48 \mathrm{~h}$ revealed the presence of all bacteria.

Regarding the simultaneous CECs abatement by UV-C alone (Figure $1 \mathrm{~b}$ ), the results showed that $80 \%$ removal of total CECs was attained after up 120 min of treatment $(2.9 \mathrm{~kJ} / \mathrm{L})$, but significant differences of the individual CEC susceptibility and removal was observed (Figure S2): DCF > SMX > TMP. This result is explained by the well-known influence of the molar absorption coefficient of each CEC and the quantum yield at the wavelength of lamp emission ( $\varepsilon 254$ and $\Phi 254$, respectively) to favor the breakdown of the compounds under radiation, concluding therefore that CECs removal by UV-C alone is highly influenced by the physicochemical structure of each compound. According to the literature, SMX has higher $\varepsilon 254$ (16500 and $61001 / \mathrm{M} \cdot \mathrm{cm}$ for SMX and DCF, respectively) but 8-fold lower $\Phi 254$ than DCF (0.058 and $0.222 \mathrm{~mol} / \mathrm{Es}$ for SMX and DCF, respectively), and for this reason, it exhibits a lower photolysis efficiency. TMP values of $\varepsilon 254$ and $\Phi 254$ are low $(29001 / \mathrm{M} \cdot \mathrm{cm}$ and $0.006 \mathrm{~mol} / \mathrm{Es})$, which may explain the lower removal rate observed with only UV-C radiation [16].

The disinfection and decontamination results obtained by UV-C alone indicate that even though this process is highly efficient for water disinfection, important limitations still remain, such as the residual microbial load and the regrowth after the treatment, as well as its limited CECs removal. Therefore, the combination of UV-C with a chemical oxidant to promote the generation of ROS to improve both CECs and bacterial abatement is necessary to safely obtain reclaimed water.

In this study, the employ of PMS as a promoter of radical's generation under UV-C determined a significant enhancement in bacteria inactivation and CECs degradation, and the testing of increased concentration from 0.01 to $0.5 \mathrm{mmol} / \mathrm{L}$ showed that the higher the PMS concentration, the faster the removal kinetics rates (Figure 1a, Tables S3 and S4).

The detection limit of the sum of all bacteria (8 LRV,DL: 1 CFU/100 mL) was achieved for PMS concentrations higher than $0.2 \mathrm{mmol} / \mathrm{L}$, which is also the minimum concentration necessary for no observing bacterial regrowth after 24 and $48 \mathrm{~h}$ of post-treatment. At these PMS concentrations (0.2-0.5 mmol/L), 4.0 $\pm 0.2 \mathrm{LRV}$ of total bacteria was achieved after 4 min with a $k_{1}$ of $(0.90 \pm 0.20) \mathrm{min}^{-1}$, obtaining slightly enhanced results compared with the UV-C process alone (3.4 LRV and a $k_{1}$ of $0.85 \pm 0.20 \mathrm{~min}^{-1}$ ). However, the significant positive effect of the use of PMS is clearly observed in the second phase of the process $\left(k_{2}\right)$, DL reached and no-regrowth (Figure 1a, Figure S2 and Table S3). The individual bacterial behavior (Figure S2) revealed the following order of bacterial inactivation: E. coli (Gram negative) $\approx P$. aeruginosa (Gram negative) $\geq E$. faecalis (Gram positive), which is similar to 
other studies reported in the literature and mainly attributed to the thicker cell wall of the Gram positive bacteria [16].

Regarding CECs removal, a significant enhancing of the removal rate of the total load when increasing the PMS concentration was obtained (Figure 1b). Focusing on each of the CECs (Figure S2), it is observed that this overall enhancement is due to the susceptibility of TMP to the PMS/UV-C process, while in the case of SMX and DCF, no significant differences were obtained in the presence and absence of PMS.

Considering simultaneous water disinfection and decontamination, the best performance was reached at $0.5 \mathrm{mmol} / \mathrm{L}$ of PMS, obtaining $8 \mathrm{LRV}$ for total bacteria after $90 \mathrm{~min}$ of treatment $(2.1 \mathrm{~kJ} / \mathrm{L})$ and $80 \%$ of CECs removal after $8 \mathrm{~min}(0.02 \mathrm{~kJ} / \mathrm{L})$. The enhancement water purification by the PMS/UV-C process is attributed to the generation of $\mathrm{SO}_{4}^{\bullet-}$ and - $\mathrm{OH}$ radicals by PMS photolysis [25]. These ROS initiate oxidative stress by attacking firstly the cell membrane and altering its permeability, although they can also permeate easily through the cell-wall membrane and further react with cellular components (enzymes and genetic materials), inhibiting normal metabolism and thus leading to cells inactivation [26]. Regarding CEC, the degradation is mainly initiated by $\mathrm{SO}_{4}^{\bullet-}$ and ${ }^{\bullet} \mathrm{OH}$ attack with second-order kinetic constants in the range of $10^{9} \mathrm{M}^{-1} \mathrm{~s}^{-1}$ [27]. However, the results demonstrated that DCF and SMX are not chemically limited, and increasing PMS concentration did not enhance significantly their degradation, which is mainly due to an important effect of only UV-C radiation on the removal of these targets (Figure S2b,d). This could be explained considering $\varepsilon, \Phi$, and the concentration of targets and oxidant. Herrmann et al. (2007) reported values of 0.012 and $19.1 \mathrm{~L} / \mathrm{mol} \mathrm{cm}$ for $\varepsilon$ and $\Phi$ of PMS, respectively [28]. Despite the PMS concentration, being $10^{4}$ times higher than CECs, DCF and SMX were able to absorb directly UV-C absorption of light due to the higher values of $\varepsilon$ and $\Phi[16]$ and photolysis is the main cause of degradation. For this reason, an increase in oxidant concentration did not involve a significant enhancement in their degradation. On the other hand, TMP degradation was mediated by $\mathrm{SO}_{4}{ }^{\bullet-}$ and ${ }^{\bullet} \mathrm{OH}$, in which PMS is more efficient than direct UV-C light absorption.

\subsection{Simultaneous Inactivation of Bacteria and Degradation of CECs in UWW}

The simultaneous inactivation of the total bacteria (including E. coli, Enterococcus spp., and Pseudomonas spp.) (Figure 2a) and the degradation of total CECs (Figure 2b) under $\mathrm{UV}-\mathrm{C}$ radiation and $\mathrm{PMS} / \mathrm{UV}-\mathrm{C}$ at oxidant concentrations ranging from 0 to $1 \mathrm{mmol} / \mathrm{L}$ has been investigated in UWW. Kinetic rate analysis and individual profiles of each target are shown in Tables S5 and S6 and Figure S3, respectively. The results obtained in this water matrix followed the same trend than the observed in SUWW; i.e., a limited process performance of UV-C alone was obtained. DL for bacterial inactivation was not reached, and low CECs removal kinetic rates were obtained; meanwhile, the addition of increasing PMS concentrations determined a great enhancement on the simultaneous CECs degradation and bacterial inactivation, detecting no regrowth of microbial targets only with concentrations higher than $0.5 \mathrm{mmol} / \mathrm{L}$. In addition, concentrations higher than $0.5 \mathrm{mmol} / \mathrm{L}$ were investigated to determine the best process performance considering the higher physicochemical and microbiological complexity of the UWW water matrix. Nevertheless, results showed no significant differences between $0.5,0.75$, and $1 \mathrm{mmol} / \mathrm{L}$ of PMS for total bacteria inactivation and CECs removal. Beyond the optimum, an enhancement was not observed due to the possible reactions between oxidant and radicals and self-recombination of active species that could exceed the ones with biological and chemical targets, as it is reported elsewhere [25]. 


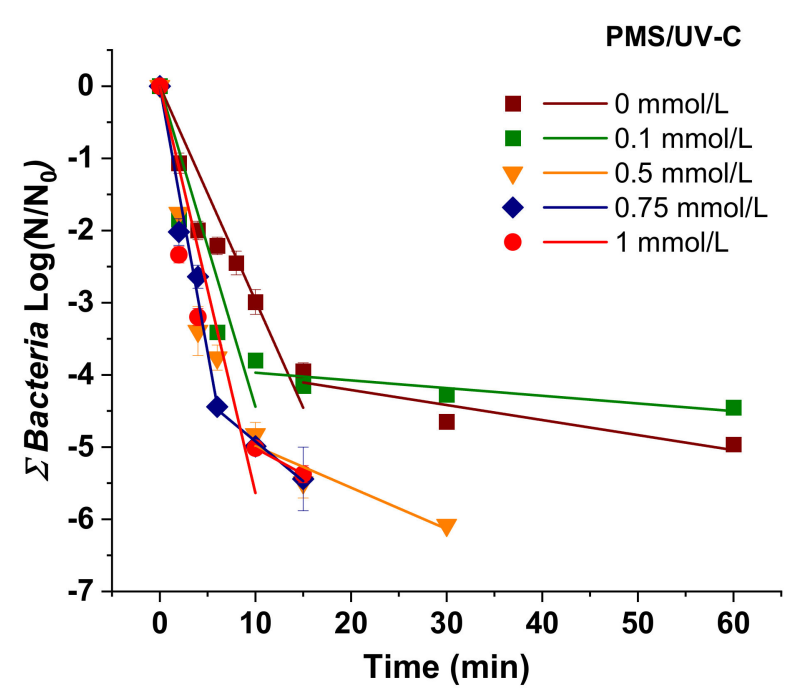

(a)

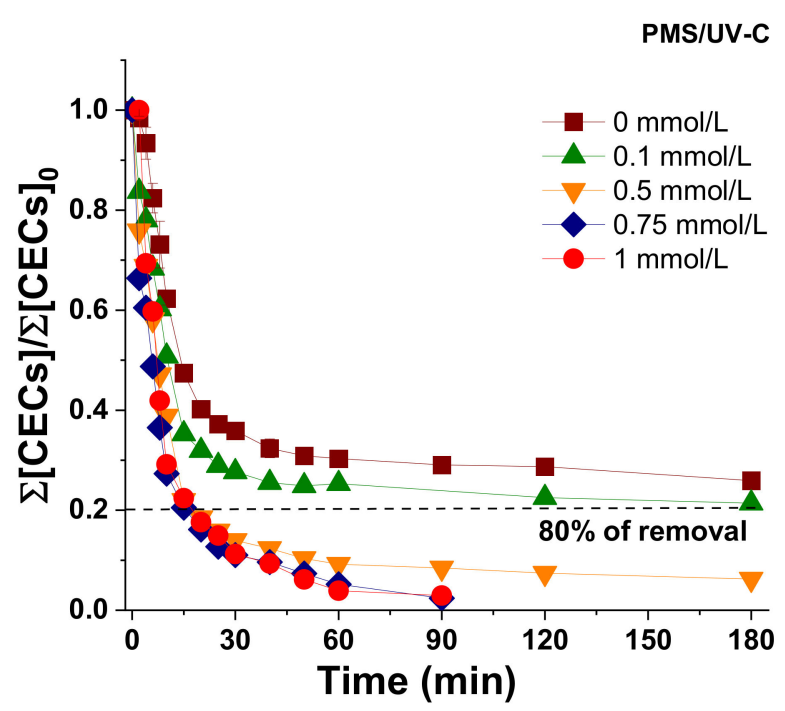

(b)

Figure 2. (a) Linear fitting of sum of bacteria inactivation; (b) Degradation of total CECs in UWW under UV-C irradiation in the presence of increasing concentration of PMS (0-1 mmol/L).

However, focusing on each individual target, this trend is also observed except for TMP, where higher PMS concentration than $0.5 \mathrm{mmol} / \mathrm{L}$ was necessary to achieve $80 \%$ of removal (Figure S3f). Therefore, these results clearly state that depending on the desired final results or quality requirements established by reclamation guidelines, the optimization of the oxidative agent concentration could vary, which also directly affects the treatment cost.

Considering the simultaneous UWW disinfection and decontamination (Figure 2), the best PMS concentration was also obtained with $0.5 \mathrm{mmol} / \mathrm{L}$. At this condition, 4.7 LRV (concentration $<10 \mathrm{CFU} / 100 \mathrm{~mL}$ ) was achieved after $10 \mathrm{~min}$ of treatment $(0.01 \mathrm{~kJ} / \mathrm{L})$ for all bacteria, and $80 \%$ of total CECs was removed after $15 \mathrm{~min}(0.04 \mathrm{~kJ} / \mathrm{L})$. For comparison, in SUWW, $80 \%$ of CECs was removed in half of the time (after $8 \mathrm{~min}$ and $0.02 \mathrm{~kJ} / \mathrm{L}$ ), while 4.5 LRV were obtained in a similar treatment time $(10 \mathrm{~min})$, which could be attributed to the higher load of microbial targets in SUWW in comparison with UWW.

It is well recognized that the water matrix significantly affects disinfection and decontamination efficiency [29]. The main natural constituents of different water matrices include natural organic matter (NOM) and inorganic species, such as $\mathrm{Cl}^{-}, \mathrm{CO}_{3}{ }^{2-} / \mathrm{HCO}_{3}{ }^{-}$, $\mathrm{SO}_{4}{ }^{2-}$, and $\mathrm{NO}_{3}{ }^{-}$. These components are ubiquitous in UWW at different concentrations and they can be involved in side reactions, promoting or inhibiting the process. Lower degradation rates could be related to PMS consumption by water constituents. In fact, PMS is able to directly oxidize $\mathrm{Cl}^{-}$into less reactive chlorine species (such as $\mathrm{Cl}_{2}$ and $\mathrm{ClO}^{-}$), and it is able to react with organic matter, as it is has been described in the literature $[25,30]$.

Another inhibiting effect could be correlated to light attenuation, which is induced by the high light absorption of NOM at $254 \mathrm{~nm}$. This filtering effect can be observed in Figure $\mathrm{S} 1$, showing different irradiance $\left(\mathrm{W} / \mathrm{m}^{2}\right)$ profiles under UV irradiation in DW, SUWW, and UWW, with lower values measured in the more complex matrix. Lower oxidant availability and light attenuation induce also a decrease of the active species $\left(\mathrm{SO}_{4}{ }^{\bullet-}\right.$ and - $\mathrm{OH})$ generated in solution. A further reduction is due to the scavenging effect, with a side reaction between inorganic species (mainly $\mathrm{Cl}^{-}$and $\mathrm{CO}_{3}{ }^{2-} / \mathrm{HCO}_{3}{ }^{-}$) and $\mathrm{NOM}$ with active radicals $\left(\mathrm{SO}_{4}{ }^{\bullet-}\right.$ and $\left.{ }^{\bullet} \mathrm{OH}\right)$, converting them into less reactive species $\left(\mathrm{Cl}^{\bullet} / \mathrm{Cl}_{2}{ }^{-}-\right.$and $\left.\mathrm{CO}_{3}{ }^{\bullet-}\right)$. Among the inorganic species, $\mathrm{SO}_{4}{ }^{2-}$ is not considered a robust radical scavenger due to its slower reaction with active radicals compared to other anions. On the other hand, $\mathrm{NO}_{3}{ }^{-}$and $\mathrm{NOM}$, under certain conditions, could act as photosensitizers, absorbing light, generating ROS in solution, and increasing degradation rates [25]. Wacławek et al. (2017) reported second-order reaction rate constants of $\mathrm{SO}_{4}{ }^{\bullet-}$ and ${ }^{\bullet} \mathrm{OH}$ with common ions and NOM (humic acids). They report that $\mathrm{k}^{\bullet} \mathrm{OH}$,inorganic ions/NOM are 10 times higher than 
$\mathrm{k}_{\mathrm{SO} 4 \bullet-\text {,inorganic ions/NOM, }}$ and for this reason, $\mathrm{SO}_{4}{ }^{\bullet-}$ exhibits high selectivity in a complex water matrix [12].

UV-C driven SR-AOPs have been studied for the degradation of different contaminants and for the inactivation of several pathogens, but only few studies involve the use of complex matrices [14,15,31-33]. Mahdi-Ahmed et al. (2014) reported Ciprofloxacin (CIP) oxidation by UV-based AOPs, comparing the performances of three oxidants, PMS, PS, and $\mathrm{H}_{2} \mathrm{O}_{2}$ in DW and UWW. UV-based AOPs significantly increased the removal efficiency in DW with all the oxidants being the order of efficiency UV $/ \mathrm{PS}>\mathrm{UV} / \mathrm{PMS}>\mathrm{UV} / \mathrm{H}_{2} \mathrm{O}_{2}>$ UV. However, in a complex water matrix, the most efficient process was UV/PMS followed by UV / PS and UV $/ \mathrm{H}_{2} \mathrm{O}_{2}$, because SR-AOPs, involving PMS and PS, were less affected by the presence of NOM and inorganic species, which was due to the limited scavenger effect toward the higher selective $\mathrm{SO}_{4}{ }^{\bullet-}$. Moreover, they correlated the higher PMS reactivity to the presence of $\mathrm{HCO}_{3}{ }^{-}$, which is capable of activating PMS. CIP (at an initial concentration of $50 \mu \mathrm{mol} / \mathrm{L}=17 \mathrm{mg} / \mathrm{L}$ ) was fully degraded in UWW at pH 7 in $60 \mathrm{~min}$ in the presence of $1 \mathrm{mmol} / \mathrm{L}$ of PMS under UV-C irradiation [31]. Rodriguez-Chueca et al. (2018) investigated among other tertiary treatments (coagulation/flocculation, filtration, and UV-C radiation with different oxidants), the PMS/UV-C process to remove 25 CECs (including antibiotics, pesticides, flame retardants, corrosion inhibitors, and synthetic fragrances) detected at trace level $(1-4 \mu \mathrm{g} / \mathrm{L})$. They tested different oxidant concentrations $(0.05,0.2$, and $0.5 \mathrm{mmol} / \mathrm{L})$ and contact times (4-18 s), reporting average removal rates of CECs of $55 \%, 48 \%$, and $10 \%$ for $\mathrm{H}_{2} \mathrm{O}_{2}$, PMS, and PS, respectively, compared to $13 \%$ with only UV-C radiation [14].

Higher treatment efficiencies than those reported in the literature were obtained in our study due to the use of a batch mode system that allowed higher contact times compared to the treatment performed in a continuous flow mode, which is commonly employed in real scenarios. However, it is important to consider that the effectiveness of a UV system depends on different parameters, such as the intensity of radiation, the contact time, the reactor configuration, and the composition of the water matrix. Systems in a continuous flow-mode are actually commonly used for disinfection purposes in drinking water treatment plants for the treatment of high-quality water characterized by low turbidity and asmall content of suspended solids, and NOM. In a complex matrix, it is necessary to take into account that disinfection and decontamination could be ineffective due to low contact times, photons scattering, and absorption effects by constituents of the water matrix, leading to a low CECs degradation efficiency and high probability of microbial regrowth.

Rodriguez-Chueca et al. (2019), in a latter work, also pointed out that the process efficiency depends on the target compound and the experimental conditions (contact time and oxidant concentration) by studying the degradation of atenonol, bisphenol A, caffeine, carbamazepine, diclofenac, ibuprofen, sulfamethoxazole, and their transformation products with low dosage of oxidant $(0.5 \mathrm{mmol} / \mathrm{L})$, obtaining good removal efficiencies only for some of them [34].

\section{3. $A R B$ and $A R G$ Removal in $U W W$}

Currently, the high concern of the scientific community about ARB and ARGs spreading has promoted the research of water treatment methods able to efficiently remove these biological targets from UWW effluents. In this study, the inactivation of ARB and the degradation of ARGs after UV-C treatment with PMS has been therefore also assessed. Figure 3a shows the inactivation of E. coli, AR-E. coli, Enterococcus spp., AR-Enterococcus spp., Pseudomonas spp., and AR-Pseudomonas spp. in UWW by PMS (1 mmol/L)/UV-C radiation. The high oxidant concentration used in the present work was selected considering previous studies $[32,35,36]$. Arslan-Alanton et al. (2021) could not detect quantifiable DNA for the genes $16 S \mathrm{rRNA}$, aphA and tet $A$ as a result of the application of PMS/UV-C treatment at a concentration of $2 \mathrm{mmol} / \mathrm{L}$ of oxidant in tertiary treated UWW [32]. In addition, a review by Michael-Kordatou et al. (2018) determined that the necessary concentration of 
oxidant for the removal of ARGs in wastewater effluents using different advanced chemical oxidation processes is higher than the corresponding concentration to inactivate ARB [35].

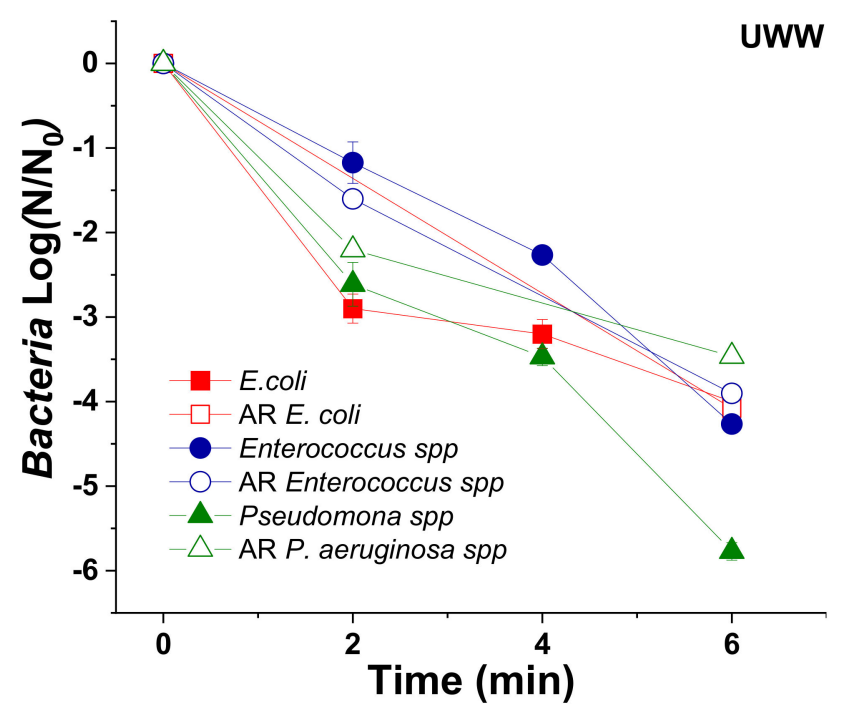

(a)

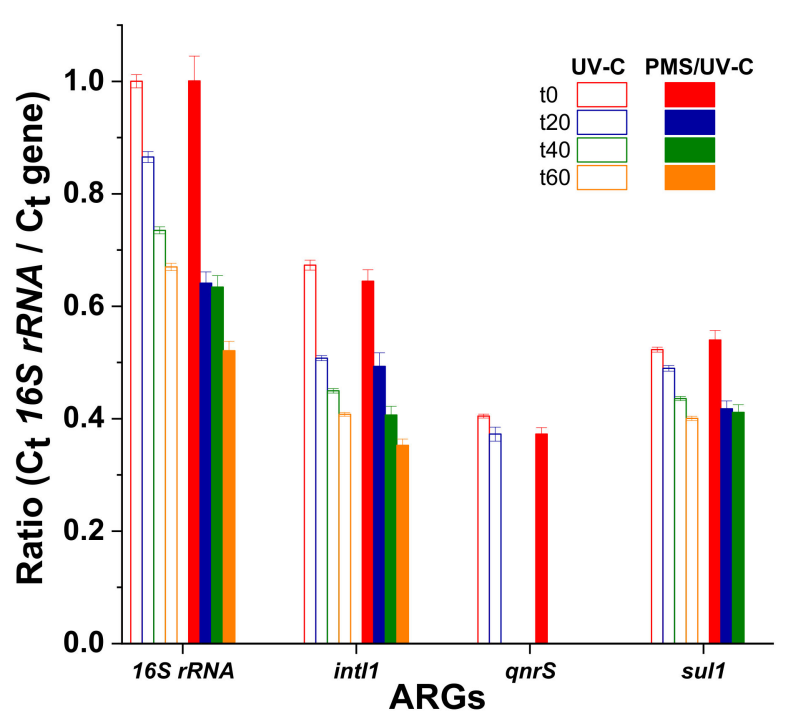

(b1)

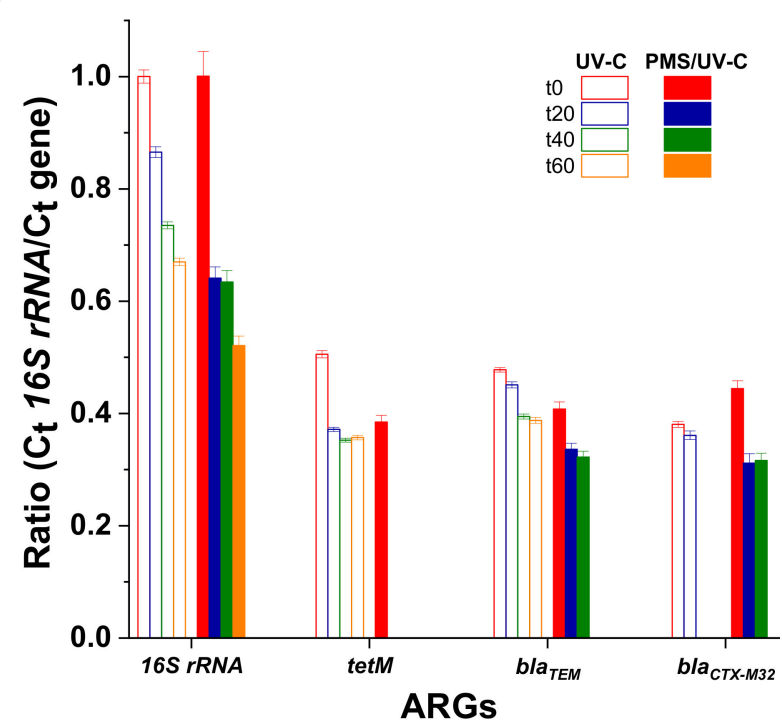

(b2)

Figure 3. (a) Inactivation of E. coli, Enterococcus spp., and Pseudomonas spp. and their Ampicillin (AMP), Ciprofloxacin (CPX) and Trimethoprim (TMP) antibiotic-resistant counterpart and $(\mathbf{b} 1, \mathbf{b} 2)$ relative abundance of each ARG (with respect to $16 S$ $r R N A)$ as a function of time under UV-C irradiation in the absence and in the presence of PMS (1 mmol/L).

Our results showed that all the wild and AR bacteria determined in this study reached the DL (1 CFU / $100 \mathrm{~mL}$ ) in $6 \mathrm{~min}$ (QUV of $0.01 \mathrm{~kJ} / \mathrm{L})$. At this time and under such operational conditions, 3 LRV of E. coli, AR-E. coli, Enterococcus spp., and AR-Enterococcus spp. were attained; while 6 LRV of Pseudomonas spp. and 3 LRV AR-Pseudomonas spp. (due to its lower initial concentration) were obtained. These results agree with a few works reporting ARB inactivation in UWW by PMS/UV-C, where 5.3 LRV of AR-Pseudomonas sp. HLS-6 was obtained after $10 \mathrm{~min}$ of treatment $\left(60 \mathrm{~mJ} / \mathrm{cm}^{2}\right)$ with $1 \mathrm{mg} / \mathrm{L}$ of PMS [37]. In addition, no significant differences in the resilience between ARB and the wild-type bacteria were obtained (Figure 3a), which agree with other studies in the literature for different oxidative processes. As already demonstrated by Fiorentino et al. (2019), the same inactivation kinetics were obtained for wild-type bacteria than for ARB in UWW after the application of a solar photo-Fenton process using raceway pond reactors at neutral $\mathrm{pH}$, pointing out 
that the inactivation of ARB is not the main issue in the treatment of wastewater, but it is the removal of ARGs [38].

The use of antibiotics in humans and animals over the years has produced ARB and encoding ARGs. Nowadays, different types of ARGs exist in the environment, such as genes conferring resistance to quinolone, tetracycline, sulfonamide, $\beta$-lactamase, cephalosporine, etc. The resistance bacteria to these antibiotics emerge from environmental exposure, as tetracycline or $\beta$-lactamase, and also from their widespread use to treat bacterial infections in both human and animal clinics, such as quinolones and sulfonamides [39-41]. Therefore, the occurrence ratio of different ARGs related with these antibiotics was initially determined in the secondary effluents of UWW from El Bobar (Almeria, Spain). It was calculated by means of their relative abundance by analyzing the $16 S$ rRNA gene, which represents the microbiological abundance in UWW. The following rank was obtained: intI1 $(0.654 \pm 0.021)>\operatorname{sul1}(0.530 \pm 0.014)>$ bla $_{\text {TEM }}(0.443 \pm 0.042)>\operatorname{tet} M(0.440 \pm 0.049)>$ bla $_{\text {CTX-M32 }}(0.408 \pm 0.091)>>$ qnrS $(0.384 \pm 0.021)$ (Data from Table S7).

The gene of class 1 integron integrase, intI1, is considered an indicator of horizontal gene transfer. For this reason, it is very important to attain its degradation, because intI1 encodes a protein involved in the integration of DNA into the cell $[42,43]$.

Throughout the PMS/UV-C radiation treatment at $1 \mathrm{mmol} / \mathrm{L}$ of oxidant, the ARGs showed different grades of degradation (Figure 3b). The quantification limit (QL) was achieved after $20 \mathrm{~min}$ of treatment $(0.3 \mathrm{~kJ} / \mathrm{L})$ for tet $M$ and $q n r S$ genes and after $60 \mathrm{~min}$ $(1.4 \mathrm{~kJ} / \mathrm{L})$ for sul1, bla $a_{T E M}$, and $b l a_{C T X-M 32}$, while $50 \%$ of degradation was observed for the $16 S$ rRNA and intI1 genes after 60 min of treatment time. However, UV-C alone, showed different grades of degradation. The QL is only reached for the $q n r S$ and $b l a_{C T X-M 32}$ genes after $40 \mathrm{~min}(0.9 \mathrm{~kJ} / \mathrm{L})$, while for the other genes, degradation percentages of $38.8 \%, 33 \%$, $29.4 \%, 23 \%$ and $18.8 \%$ were obtained after 60 min of treatment for intI1, 16srRNA, tetM, sul1, and $b l a_{T E M}$, respectively. Comparing the results of both UV-C and PMS/UV-C, it can be determined that the highest degradation of ARGs is obtained when PMS oxidant is present.

Very few studies in the literature report on the removal rate of ARGs in UWW by UV-C and its combination with PMS. Rodríguez-Chueca et al. (2019) reported ARGs (bla $a_{T E M}$, sul1, and $q n r S$ ) removal in UWW by different oxidation processes (UV-C alone, $\mathrm{UV}-\mathrm{C} / \mathrm{H}_{2} \mathrm{O}_{2}$ and UV-C/PMS). They concluded, from the results obtained after $4 \mathrm{~s}$ of contact time $(0.41 \mathrm{log}, 0.21 \mathrm{log}$, and $0.22 \mathrm{log})$, that the most effective treatment for the removal of ARGs is UV-C radiation alone, which is followed by UV-C/PMS (at $0.5 \mathrm{mmol} / \mathrm{L}$ ). This effect was attributed to the UV photons scavenger by oxidants in detriment to DNA photoabsorption, reducing the direct damage to the genes. In addition, the LOQ of the investigated genes was not reached probably due to the very low contact time (4 s of UV-C irradiance) [33], which were much lower than those covered in the present study (60 min of treatment time, corresponding to $300 \mathrm{~s}$ of UV-C irradiance).

$\mathrm{Hu}$ et al. (2019) reported reduction rates of $2.9 \mathrm{log}$ and $3.4 \mathrm{log}$ for sul1 and intI1 genes, respectively, after the treatment with UV-C $\left(180 \mathrm{~mJ} / \mathrm{cm}^{2}\right)$ and $20 \mathrm{mg} / \mathrm{L}$ of PMS during $30 \mathrm{~min}$ in $50 \mathrm{~mL}$ of phosphate buffer saline solution. They also compared different treatments (UV-C, PMS, and UV-C/PMS) for both genes obtaining a lower ARGs reduction rate of $1.2 \mathrm{log}$ and $0.8 \mathrm{log}$ (sul1 and intI1, respectively) after $30 \mathrm{~min}$ of UV-C treatment alone. Hence, they concluded that $\mathrm{SO}_{4}{ }^{\bullet-}$ radicals were responsible for the reduction of genes by direct attack to DNA [37].

Likewise, Arslon-Alanton et al. (2021) reported the LOQ for genes $16 S r R N A$, aphA, and tet $A$ after the treatment of $500 \mathrm{~mL}$ of tertiary UWW with UV-C $\left(0.45 \mathrm{~W} / \mathrm{m}^{2}\right)$ and the oxidant PMS (2 mmol/L) at a contact time of $80 \mathrm{~min}$. The authors also compared the application of the treatment UV-C alone, obtaining only a removal rate of $3.27 \pm 0.07 \mathrm{log}$ for $16 S r R N A$ and $2.99 \pm 0.44 \log$ for $a p h A$, concluding that the addition of strong oxidation agents such as PMS enhances the removal of ARGs in tertiary UWW [32].

The results of the present study on the removal of ARGs determine that UV-C treatment with the oxidant PMS is more efficient than UV-C alone. 
It is well known that the UV-C radiation induces a germicidal effect by producing the formation of cyclobutane pyrimidine dimers (CPDs) in the DNA. However, according to the literature consulted, it is not already experimentally demonstrated that the $\mathrm{SO}_{4}{ }^{\bullet-}$ produced during the treatment with UV-C causes damage to ARGs [9].

The results obtained for ARB inactivation and ARGs removal after PMS/UV-C treatment demonstrate its promising efficiency; an exposure time of $60 \mathrm{~min}$ was necessary to achieve $50 \%$ removal of the $16 S$ rRNA and intI1 genes and the quantification limit for the sul1, bla $a_{T E M}, b_{C} a_{C T X-M 32}, q n r S$ and tetM genes. The inactivation of ARB alone does not guarantee DNA damage, which may be present and undamaged, being able to contribute to antibiotic resistance spread through different transmission mechanisms. Therefore, it is important to consider both ARB and ARGs as unique targets in future disinfection strategies.

\subsection{Toxicity Assessment}

Figure 4a shows the bioluminescence inhibition (BI) results toward A. fischeri. It is observed that the luminescence emitted by the marine bacterium was not significantly affected, as the BI \% values were $-44.5 \pm 12,1.5 \pm 2.1,-6 \pm 0$, and $-18.5 \pm 4.9$ for the UWW matrix, UWW with PMS addition (Time 0), and treated UWW (40 and $90 \mathrm{~min}$ of treatment time), respectively. An eco-toxicity result of $<20 \%$ indicates that the discharge of UWW treated by PMS/UV-C does not pose a harmful effect to the receiving aquatic environment (non-acute toxicity) [44]. Nevertheless, it is also important to note that the mere effect of PMS addition led to a significant bioluminescence decrease with respect to the UWW matrix (46 BI \% increase) followed by a toxicity reduction (BI \% decrease) at the end of the treatment time. A similar effect has been previously reported by Deng et al. (2017) in river water with $1 \mathrm{mmol} / \mathrm{L}$ of PMS. They found $65 \mathrm{BI} \%$ at the same PMS concentration and a decrease in the toxic effect along the treatment time [45]. Results obtained in the present study also agree with the toxicity of PMS to microorganisms reported by the European Chemicals Agency (ECHA), where an $\mathrm{EC}_{50}$ value of $179 \mathrm{mg} / \mathrm{L}$ was reported for a growth inhibition test of the Gram negative bacterium P. putida [46].

Figure $4 \mathrm{~b}$ shows the phytotoxicity results for L. sativum and S. alba, indicating a growth inhibition with respect to the negative control (UWW) for both untreated (0 min) and treated UWW (40 min): root growth length ca. 30 and 20\% lower after PMS addition (RGI values) and an additional reduction of ca. $10 \%$ after UV exposure, respectively. No significant effects in $S$. saccharatum tests for 0 min samples or 40 min simples were observed.

Regarding phytotoxicity assessment, it is important to note that the PMS salt suffers an abiotic decomposition, being rapidly decomposed into products of no concern and ubiquitously present in the environment (potassium, hydrogen sulfate, hydrogen peroxide, and oxygen) upon contact with soils ( $\mathrm{DT}_{50}<11 \mathrm{~min}$ and no detection after $1 \mathrm{~h}$ ) [46]. Therefore, the phytotoxicity results obtained should be taken into account as another trophic level of environmental toxicity assessment or as representative results but only for agriculture-aquaculture systems. According to the results obtained after PMS/UV-C treatment (Figure $4 b, 40 \mathrm{~min}$ ), the treated UWW generated had a slightly toxic effect (RGI < $0.8)$ toward L. sativum and S. alba, whereas a non-toxic effect $(0.8 \leq \mathrm{RGI} \leq 1.2)$ was observed for S. saccharatum. The weakest response by Sorghum and the high sensitivity of the other two plant species observed has also been previously reported indicating the suitability of L. sativum and S. alba as indicators for the assessment of the biological effect on plants and the lack of suitability of very resistant species such as Sorghum [47-49].

Another inherent issue associated to PMS addition may be the release of sulfate and potassium ions. Under tested experimental conditions and after PMS ( $1 \mathrm{mmol} / \mathrm{L}) / \mathrm{UV}-\mathrm{C}$ treatment, increases in the UWW concentrations of potassium and sulfate ions of ca. 85 and $165 \mathrm{mg} / \mathrm{L}$ were observed, respectively. Regarding a potential UWW discharge in coastal or surface waters, limits neither for potassium nor for sulfate are established. The final concentration after the treatment is lower than the level to impart undesirable taste in drinking water (250-500 mg/L) and to cause illnesses such as diarrhea (>1000 mg/L) [50]. 
On the opposite side, when the intended end use of the treated WW is agricultural reuse, the presence of a higher potassium concentration than the usual range in irrigation water $(0-2 \mathrm{mg} / \mathrm{L})$ and an additional sulfate concentration represent an added benefit to the farmer through the saving of essential fertilizers [51].

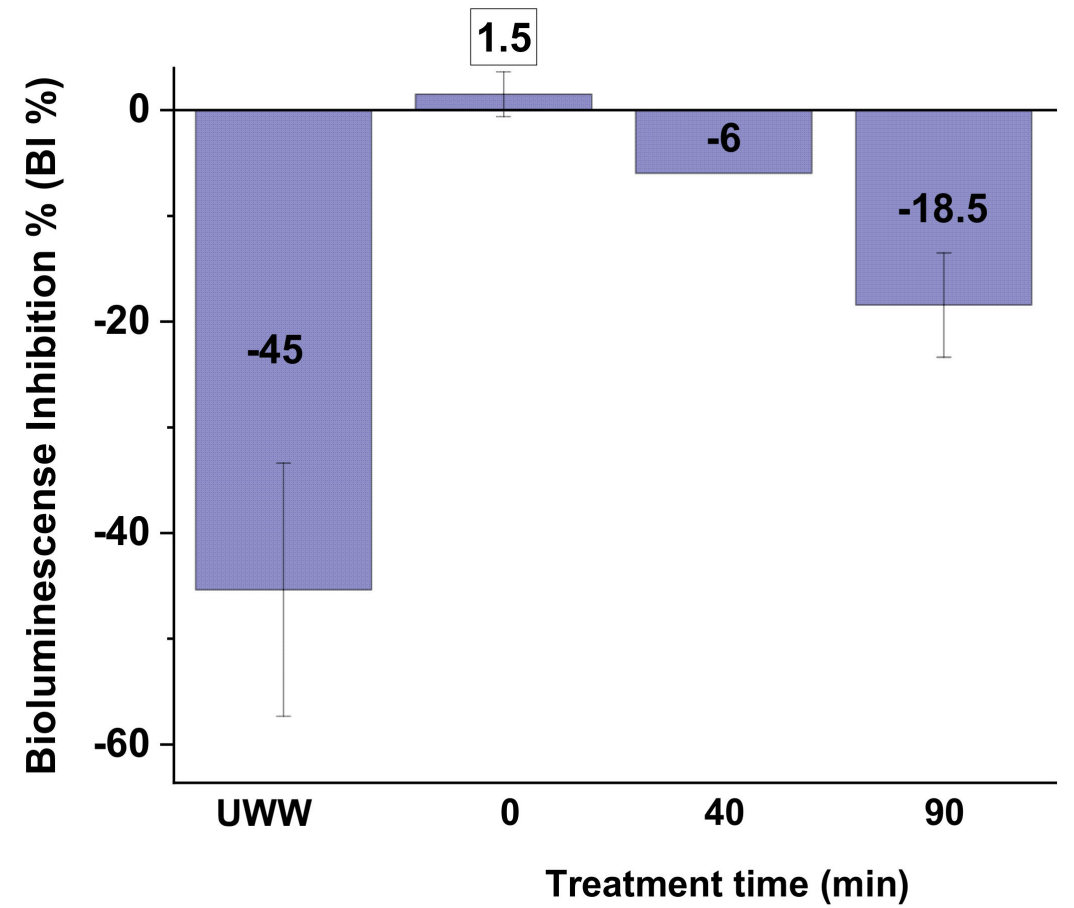

(a)

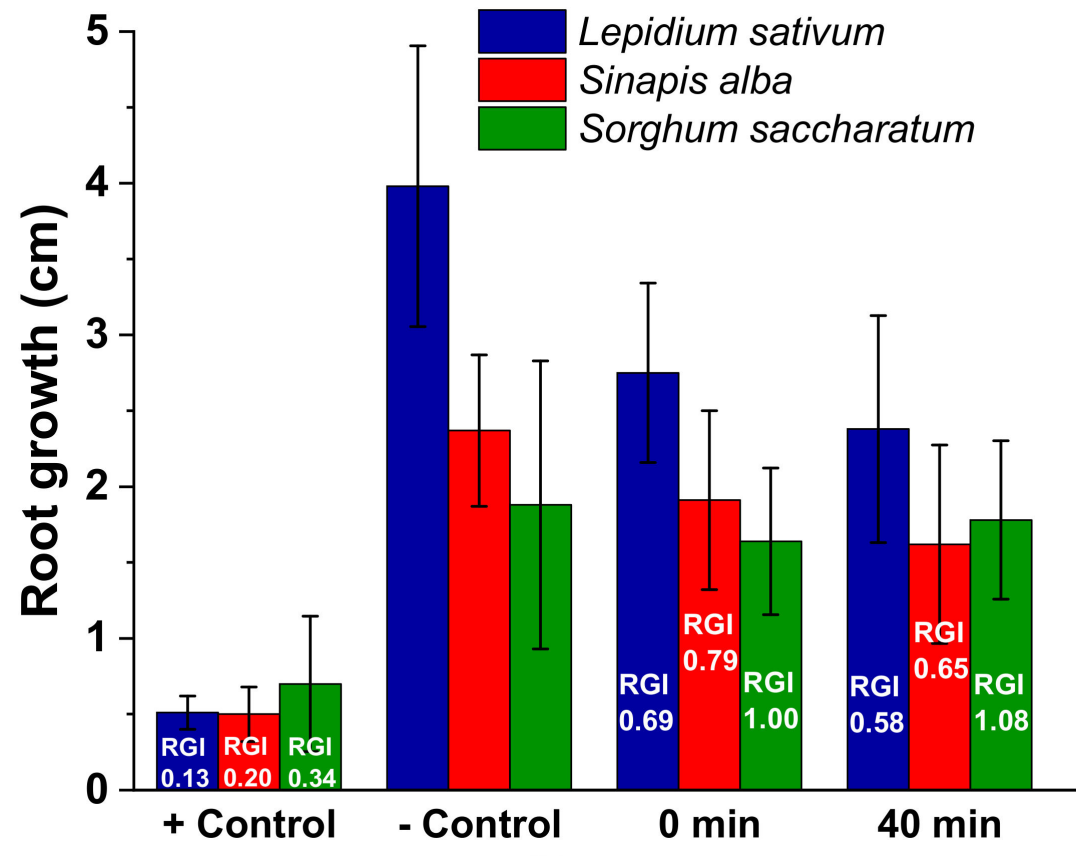

(b)

Figure 4. (a) A. fischeri bioluminescence inhibition (BI) (negative values state for stimulation effect instead of inhibition) and (b) phytotoxicity test in $\mathrm{Zn}^{2+}$ solution (positive (+) control), UWW (negative (-) control), and UWW samples treated by PMS/UV-C (1 mmol/L). 


\subsection{Cost Analysis}

Table 1 shows the estimation of the annual treatment costs (ATC) associated with the implementation of the UV-C and PMS/UV-C processes as tertiary UWW treatments (after the biological step) in an already working UWWTP, taking into account a scalingup from the results and the UV-C pilot plant used in the study (total volume $80 \mathrm{~L}$, flow rate $36 \mathrm{~L} / \mathrm{min}$, irradiance $0.2 \mathrm{~W} / \mathrm{m}^{2}$, and $6 \mathrm{~L}$ of illuminated volume). The calculations were done for the treatment of ca. $1000 \mathrm{~m}^{3}$ / day in a continuous flow UV-C reactor, i.e., considering only a single irradiation step of $2 \mathrm{~min}$ total treatment time, $10 \mathrm{~s} \mathrm{UV-C}$ contact time, and $12 \mathrm{~mJ} / \mathrm{cm}^{2} \mathrm{UV}$-dose.

The investment, operational, and maintenance costs were estimated according to the United States Environmental Protection Agency (USEPA) report considering the UV-C dose of $12 \mathrm{~mJ} / \mathrm{cm}^{2}$ (6 lamps required), a medium flow rate (USEPA category 3) of ca. $1000 \mathrm{~m}^{3}$ (0.27 MGD, million gallon day), and a capital recovery factor (CRF) of 0.117 (cost amortized at $10 \%$ for 20 years) [52].

Table 1. Breakdown of the estimated UV-C and PMS/UV-C annual costs for UWW treatment in a continuous flow reactor.

\begin{tabular}{|c|c|}
\hline Investment Costs & $1301 €$ \\
\hline Equipment cost $(\mathrm{EC})$ & $1085 €$ \\
\hline Engineering and installation (20\% of EC) & $216 €$ \\
\hline Operational and Maintenance Costs & $7213 €$ \\
\hline Replacement (lamps): 6 UV-C lamps $(8760$ h) × $820 € /$ lamp [53] & $4920 €$ \\
\hline $\begin{array}{l}\text { Power: } 4468 \mathrm{kWh} \text { (lamps) and 11,643 kWh (pumping) }=16,111 \mathrm{kWh} \times \\
0.12 € / \mathrm{m}^{3}[54]\end{array}$ & $1933 €$ \\
\hline Labor $(36 \mathrm{~h})(0.5 \mathrm{~h}$ per month per lamp for cleaning and repair $) \times 10 € / \mathrm{h}$ & $360 €$ \\
\hline UV-C Total Cost & $\begin{array}{c}8514 € \\
0.02 € / \mathrm{m}^{3}\end{array}$ \\
\hline UV-C + $0.5 \mathrm{mmol} / \mathrm{L}$ PMS & $\begin{array}{c}120,450 € \\
0.33 € / \mathrm{m}^{3}\end{array}$ \\
\hline $\mathrm{UV}-\mathrm{C}+0.75 \mathrm{mmol} / \mathrm{L}$ PMS & $\begin{array}{c}176,414 € \\
0.48 € / \mathrm{m}^{3}\end{array}$ \\
\hline UV-C + $1 \mathrm{mmol} / \mathrm{L}$ PMS & $\begin{array}{l}231,164 € \\
0.63 € / \mathrm{m}^{3}\end{array}$ \\
\hline
\end{tabular}

The ATC value estimated for UWW treatment by UV-C alone was $8514 €$, which lead to a treatment cost of $0.02 € / \mathrm{m}^{3}$. Whereas the costs for PMS/UV-C treatment increased to $0.33,0.48$, and $0.63 € / \mathrm{m}^{3}$ for $0.5,0.75$, and $1 \mathrm{mmol} / \mathrm{L}$ of PMS, respectively. This increment is mainly consequence of the reagent cost $(2 € / \mathrm{kg}$ or $0.61 € / \mathrm{mol}$ of commercial PMS salt), which represents $>95 \%$ of the total treatment cost. Costs associated to an intermediate tank (to dissolve the PMS salt) and a dispenser pump were not considered due to their costs being negligible with respect to reagent costs. The estimated treatment costs are in agreement with the previous one reported in the literature for UWW: 0.012 and $0.585 € / \mathrm{m}^{3}$ for UV-C and UV-C/PMS (0.5 mmol/L) [15].

The figure of merit Electrical Energy per Order (EEO) (Table 2) was also calculated (Equation (2), [55]) for both disinfection and CECs removal under the experimental conditions of the present work, as another usual descriptor to compare different treatments.

$$
E E O=\frac{P(k W)}{F\left(\frac{m^{3}}{h}\right) \times \log \left(\frac{C_{i}}{C_{f}}\right)}
$$

where $P$ is the rated power $(0.3 \mathrm{~kW}$, lamp $(0.23 \mathrm{~kW})+$ pump $(0.07 \mathrm{~kW})), t$ is the treatment time ( $2 \mathrm{~min}$ for flow conditions and the treatment time needed to achieve the Swiss guideline treatment goal ( $80 \%$ of removal) for batch or recirculation mode) [18], $V$ is the 
treated volume ( $80 \mathrm{~L})$, and $C_{i}$ and $C_{f}$ are the initial and final concentration of the target for both UV-C and PMS/UV-C (0.5 mmol/L) (Table S8).

Table 2. Energy per order (EEO, $\mathrm{kWh} / \mathrm{m}^{3}$ ) for UWW treatment (disinfection and CECs removal) in continuous flow (one path throughout lamp) and batch conditions by UV-C and PMS/UV-C $(0.5 \mathrm{mmol} / \mathrm{L})$ processes.

\begin{tabular}{ccccc}
\hline & \multicolumn{2}{c}{ EEO $\left(\mathbf{k W h} / \mathbf{m}^{\mathbf{3}}\right)$} \\
\hline & $\begin{array}{c}\text { E. coli } \\
\text { Continuous } \\
\text { Flow (2 min) }\end{array}$ & $\begin{array}{c}\text { Batch Mode } \\
(\leq \mathbf{1 0} \text { CFU/100 } \mathbf{~ m L})\end{array}$ & $\begin{array}{c}\text { Continuous } \\
\text { Flow } \mathbf{2} \text { min })\end{array}$ & $\begin{array}{c}\text { Batch Mode } \\
(\geq \mathbf{8 0} \% \text { Removal } \\
\mathbf{\Sigma} \text { CECs })\end{array}$ \\
\hline UV-C & 0.25 & 0.41 & 14.22 & 19.23 \\
\hline $\begin{array}{c}\text { PMS/UV-C } \\
(0.5 \mathrm{mmol} / \mathrm{L})\end{array}$ & 0.08 & 0.20 & 1.04 & 1.07 \\
\hline
\end{tabular}

The efficiency data used to compare both treatments in terms of EEO are shown in Table S8. Lower energy requirements $\left(\mathrm{kWh} / \mathrm{m}^{3}\right)$ for both treatments goals (disinfection and CECs removal) and operational modes (flow and batch) were obtained for the PMS/UV-C process. For the continuous flow mode, significant lower energy requirements ( $\geq 3$ and 13 times lower for disinfection and CECs removal, respectively) and significant higher treatment efficiencies (increases of $>1 E$. coli LRV, $>25 \%$ of CECs removal) were observed for the PMS/UV-C process with respect to the conventional UV-C process alone. Moreover, if the treatment goals are taking into account (quality regulations/guidelines), which are linked with higher UV-C doses (higher treatment times through batch mode operation), the energy requirements are not significantly higher with respect to the continuous flow mode for the PMS/UV-C process ( 0.08 to $0.20 \mathrm{kWh} / \mathrm{m}^{3}$ and 1.04 to $1.07 \mathrm{kWh} / \mathrm{m}^{3}$ for disinfection and CECs removal, respectively).

According to the treatment costs obtained, it is clear that based only on economic aspects, the combination of PMS with UV-C treatment is not economically competitive (mainly associated with reagents costs). Nevertheless, if the treatment efficiencies, the water quality guidelines requirements, and the energy demand associated (significant lower for PMS/UV-C) are considered (Table S8), the UV-C/PMS alternative becomes a promising process for the near future in both operation modes (continuous flow and batch).

\section{Conclusions}

The combination of PMS (as oxidant agent) with UV-C irradiation (a commonly tertiary disinfection treatment used in UWWTPs) has been demonstrated to successfully address wastewater reuse challenges regarding fecal bacterial load (E. coli, Pseudomonas spp., and Enterococcus spp.), ARB and ARGs removal, CECs degradation, toxicity, and costs.

The best PMS concentration was found to be $0.5 \mathrm{mmol} / \mathrm{L}$, at which limits on bacterial concentration $<10 \mathrm{CFU} / 100 \mathrm{~mL}$ were achieved after $10 \mathrm{~min}$ of treatment $(0.01 \mathrm{~kJ} / \mathrm{L})$ for all bacteria investigated, following the order of susceptibility according to their inactivation kinetic rate: E. coli > Pseudomonas spp. > Enterococcus spp. Regarding organic chemical pollutants, $80 \%$ of the total CECs analyzed (DCF $>$ SMX > TMP) was removed after $15 \mathrm{~min}$ $(0.04 \mathrm{~kJ} / \mathrm{L})$.

Higher oxidant load ( $1 \mathrm{mmol} / \mathrm{L})$ effectively removed ARB and ARGs. Significant differences in the inactivation of wild and AR-bacteria were not observed, and DL of $1 \mathrm{CFU} / 100 \mathrm{~mL}$ was reached after $6 \mathrm{~min}$ of treatment $(0.01 \mathrm{~kJ} / \mathrm{L})$ for all microbial targets. The quantification limit of the genes sul1, $b l a_{T E M}, b l a_{C T X-M 32}, q n r S$, and tetM genes was reached within $60 \mathrm{~min}$ of treatment, while only $50 \%$ of the $16 \mathrm{~S} r R N A$ and intI1 was removed, and higher efficiencies were obtained compared with UV-C alone. These results clearly highlight that ARB is not the challenge on UWW; rather, it is the removal of ARGs. 
Toxicity studies were also performed to evaluate the oxidant harmful effect toward the receiving aquatic environment (considering effluent discharge) or for plants' growth (considering effluent reuse in agriculture). A significant potential toxicity toward the aquatic ecosystem was not observed by evaluating $A$. fischeri bioluminescence inhibition, while the growth of L. satioum and S. alba was little affected. The transformation products generated during the treatment investigated in this study are also of concern, and they will be deeply analyzed in a further study.

From an economic point of view and comparing with UV-C alone, an increment in the cost for PMS/UV-C process, mainly due to the reagent price, is totally counterbalanced by a higher efficiency in the simultaneous removal of chemical and biological targets, avoiding bacterial regrowth and making wastewater reuse safer. Therefore, the PMS/UV-C process could be a suitable option to be implemented in UWWTPs.

Supplementary Materials: The following are available online, Table S1: Physicochemical and microbiological characterization of SUWW and UWW, Table S2: Conditions used in qPCR real-time assays, Table S3: Inactivation kinetic constants of E. coli, E. faecalis, and P. aeruginosa in SUWW, Table S4: Pseudo-first-order degradation kinetic constants of Trimethoprim (TMP), Sulfamethoxazole, and Diclofenac (DCF) in SUWW, Table S5: Inactivation kinetic constants of E. coli, Total Coliforms, Enterococcus spp., and Pseudomonas spp. in UWW, Table S6: Pseudo-first-order degradation kinetic constants of Trimethoprim (TMP), Sulfamethoxazole (SMX), and Diclofenac (DCF) in UWW, Table S7: ARGs means and standard deviation of the ratio detected in this study, Table S8: Treatment efficiencies achieved in continuous flow (after $2 \mathrm{~min}$ ) and in batch mode (considering the treatment time to achieve E. coli $\leq 10 \mathrm{CFU} / 100 \mathrm{~mL}$ and $80 \%$ of removal of CECs) by UV-C and PMS/UV-C $(0.5 \mathrm{mmol} / \mathrm{L})$, Figure S1: UV-C lamp irradiance $\left(\mathrm{W} / \mathrm{m}^{2}\right)$ profiles registered in demineralized water (as baseline), SUWW and UWW, Figure S2: Inactivation profiles of E. coli (a), E. faecalis (c), and $P$. aeruginosa (e) and degradation profiles of DCF (b), SMX (d), and TMP (f) in the presence of increasing concentrations of PMS (0-0.5 mmol/L) and under UV-C irradiation in SUWW. Inserts: Enlargement of degradation curves, Figure S3: Inactivation profiles of E. coli (a), Enterococcus spp. (c), and Pseudomonas spp. (e) and degradation profiles of DCF (b), SMX (d), and TMP (f) in the presence of increasing concentrations of PMS ( $0-1 \mathrm{mmol} / \mathrm{L})$ and under UV-C irradiation in UWW. Inserts: Enlargement of degradation curves, Figure S4: PMS concentration decrease in function of time (min) and accumulative UV energy QUV $(\mathrm{kJ} / \mathrm{L})$ under UV-C treatment at different PMS concentrations in SUWW (0.01-0.5 mmol/L) (a) and in UWW (0.1-1 mmol/L) (b).

Author Contributions: Conceptualization, M.I.P.-L.; methodology, I.B., S.N.-G. and M.J.A.-L.; formal analysis, I.B., S.N.-G. and M.J.A.-L.; investigation, I.B.; data curation, I.B., S.N.-G., M.J.A.-L., I.O. and M.I.P.-L.; writing—original draft preparation, I.B., S.N.-G. and M.J.A.-L.; writing—review and editing, M.I.P.-L. and I.O.; supervision, M.I.P.-L.; project administration and funding acquisition, I.O. All authors have read and agreed to the published version of the manuscript.

Funding: This work is part of a project that has received funding from the European Union's Horizon 2020 research and innovation programme under the Marie Skłodowska-Curie Grant Agreement No 765860 (AQUAlity).

Data Availability Statement: Not applicable.

Acknowledgments: The authors wish to thank also the Spanish Minister of Science and Innovation for funding NAVIA Project (Reference: PID2019-110441RB-C32).

Conflicts of Interest: The authors declare no conflict of interest.

\section{References}

1. Giakoumis, T.; Vaghela, C.; Voulvoulis, N. The Role of Water Reuse in the Circular Economy, 1st ed.; Elsevier Inc.: Amsterdam, The Netherlands, 2020; Volume 5.

2. The European Parliament and the Council of the European Union Regulation (EU) 2020/741 of 25 May 2020 on minimum requirements for water reuse. Off. J. Eur. Union 2020, 2019, L177/32-L177/55.

3. Rizzo, L.; Gernjak, W.; Krzeminski, P.; Malato, S.; McArdell, C.S.; Perez, J.A.S.; Schaar, H.; Fatta-Kassinos, D. Best available technologies and treatment trains to address current challenges in urban wastewater reuse for irrigation of crops in EU countries. Sci. Total Environ. 2020, 710, 136312. [CrossRef] 
4. Gogoi, A.; Mazumder, P.; Tyagi, V.K.; Tushara Chaminda, G.G.; An, A.K.; Kumar, M. Occurrence and fate of emerging contaminants in water environment: A review. Groundw. Sustain. Dev. 2018, 6, 169-180. [CrossRef]

5. Christou, A.; Papadavid, G.; Dalias, P.; Fotopoulos, V.; Michael, C.; Bayona, J.M.; Piña, B.; Fatta-Kassinos, D. Ranking of crop plants according to their potential to uptake and accumulate contaminants of emerging concern. Environ. Res. 2019, 170, 422-432. [CrossRef]

6. Christou, A.; Agüera, A.; Bayona, J.M.; Cytryn, E.; Fotopoulos, V.; Lambropoulou, D.; Manaia, C.M.; Michael, C.; Revitt, M.; Schröder, P.; et al. The potential implications of reclaimed wastewater reuse for irrigation on the agricultural environment: The knowns and unknowns of the fate of antibiotics and antibiotic resistant bacteria and resistance genes-A review. Water Res. 2017, 123, 448-467. [CrossRef]

7. WHO New Report Calls for Urgent Action to Avert Antimicrobial Resistance Crisis. Available online: https://www.who.int/ news/item/29-04-2019-new-report-calls-for-urgent-action-to-avert-antimicrobial-resistance-crisis (accessed on 13 June 2021).

8. Wang, J.; Chu, L.; Wojnárovits, L.; Takács, E. Occurrence and fate of antibiotics, antibiotic resistant genes (ARGs) and antibiotic resistant bacteria (ARB) in municipal wastewater treatment plant: An overview. Sci. Total Environ. 2020, 744, 140997. [CrossRef]

9. Umar, M.; Roddick, F.; Fan, L. Moving from the traditional paradigm of pathogen inactivation to controlling antibiotic resistance in water-Role of ultraviolet irradiation. Sci. Total Environ. 2019, 662, 923-939. [CrossRef] [PubMed]

10. Xia, X.; Zhu, F.; Li, J.; Yang, H.; Wei, L.; Li, Q.; Jiang, J.; Zhang, G.; Zhao, Q. A Review Study on Sulfate-Radical-Based Advanced Oxidation Processes for Domestic/Industrial Wastewater Treatment: Degradation, Efficiency, and Mechanism. Front. Chem. 2020, 8, 592056. [CrossRef] [PubMed]

11. Guerra-Rodríguez, S.; Rodríguez, E.; Singh, D.N. Assessment of Sulfate Radical-Based Advanced Oxidation Processes for Water and Wastewater Treatment: A Review Assessment of Sulfate Radical-Based Advanced Oxidation Processes for Water and Wastewater Treatment: A Review. Water 2018, 10, 1828. [CrossRef]

12. Wacławek, S.; Lutze, H.V.; Grübel, K.; Padil, V.V.T.; Černík, M.; Dionysiou, D.D. Chemistry of persulfates in water and wastewater treatment: A review. Chem. Eng. J. 2017, 330, 44-62. [CrossRef]

13. Lee, J.; Von Gunten, U.; Kim, J.H. Persulfate-Based Advanced Oxidation: Critical Assessment of Opportunities and Roadblocks. Environ. Sci. Technol. 2020, 54, 3064-3081. [CrossRef]

14. Rodríguez-Chueca, J.; Laski, E.; García-Cañibano, C.; Martín de Vidales, M.J.; Encinas; Kuch, B.; Marugán, J. Micropollutants removal by full-scale UV-C/sulfate radical based Advanced Oxidation Processes. Sci. Total Environ. 2018, 630, $1216-1225$. [CrossRef] [PubMed]

15. Rodríguez-Chueca, J.; García-Cañibano, C.; Lepistö, R.J.; Encinas, Á.; Pellinen, J.; Marugán, J. Intensification of UV-C tertiary treatment: Disinfection and removal of micropollutants by sulfate radical based Advanced Oxidation Processes. J. Hazard. Mater. 2019, 372, 94-102. [CrossRef]

16. Sánchez-Montes, I.; Salmerón García, I.; Rivas Ibañez, G.; Aquino, J.M.; Polo-López, M.I.; Malato, S.; Oller, I. UVC-based advanced oxidation processes for simultaneous removal of microcontaminants and pathogens from simulated municipal wastewater at pilot plant scale. Environ. Sci. Water Res. Technol. 2020, 6, 2553-2566. [CrossRef]

17. Berruti, I.; Oller, I.; Polo-Lopez, M.I. Direct oxidation of peroxymonosulfate under natural solar radiation: Accelerating the simultaneous removal of organic contaminants and pathogens from water. Chemosphere 2021, 279, 130555. [CrossRef] [PubMed]

18. The Swis Federal Council Waters Protection Ordinance (WPO). Available online: https://www.fedlex.admin.ch/eli/cc/1998/286 3_2863_2863/en (accessed on 10 August 2021).

19. Rocha, J.; Cacace, D.; Kampouris, I.; Guilloteau, H.; Jäger, T.; Marano, R.B.M.; Karaolia, P.; Manaia, C.M.; Merlin, C.; FattaKassinos, D.; et al. Inter-laboratory calibration of quantitative analyses of antibiotic resistance genes. J. Environ. Chem. Eng. 2020, 8, 102214. [CrossRef]

20. Das Neves, G. Expression of blaCTX-M2 and invA genes of Salmonella Heidelberg isolated from poultry by Qpcr. Ann. Mol. Genet. Med. 2020, 4, 006-011. [CrossRef]

21. EN ISO 18763:2020—Soil Quality—Determination of the Toxic Effects of Pollutants on Germination. Available online: https:// standards.iteh.ai/catalog/standards/cen/520f9488-9609-48d2-a11b-d3b06f16bb68/en-iso-18763-2020 (accessed on 4 July 2021).

22. AUDE Orden de 13 de Julio de 1993 Por la Que se Aprueba la Instrucción Para el Proyecto de Conducciones de Vertidos Desde Tierra al Mar. 1995. Available online: https://www.boe.es/buscar/doc.php?id=BOE-A-1993-19593 (accessed on 10 August 2021).

23. U.S. Environmental Protection Agency. Protocols for Short Term Toxicity Screening of Hazardous Waste Sites; U.S. Environmental Protection Agency: Chicago, IL, USA, 1988.

24. Young, B.J.; Riera, N.I.; Beily, M.E.; Bres, P.A.; Crespo, D.C.; Ronco, A.E. Toxicity of the effluent from an anaerobic bioreactor treating cereal residues on Lactuca sativa. Ecotoxicol. Environ. Saf. 2012, 76, 182-186. [CrossRef]

25. Yang, Q.; Ma, Y.; Chen, F.; Yao, F.; Sun, J.; Wang, S.; Yi, K.; Hou, L.; Li, X.; Wang, D. Recent advances in photo-activated sulfate radical-advanced oxidation process (SR-AOP) for refractory organic pollutants removal in water. Chem. Eng. J. 2019, 378, 122149. [CrossRef]

26. Xiao, R.; Liu, K.; Bai, L.; Minakata, D.; Seo, Y.; Kaya Göktaş, R.; Dionysiou, D.D.; Tang, C.J.; Wei, Z.; Spinney, R. Inactivation of pathogenic microorganisms by sulfate radical: Present and future. Chem. Eng. J. 2019, 371, 222-232. [CrossRef]

27. Wojnárovits, L.; Takács, E. Rate constants of sulfate radical anion reactions with organic molecules: A review. Chemosphere 2019, 220, 1014-1032. [CrossRef] [PubMed] 
28. Herrmann, H. On the photolysis of simple anions and neutral molecules as sources of $\mathrm{O}-/ \mathrm{OH}, \mathrm{SOx}-$ and $\mathrm{Cl}$ in aqueous solution. Phys. Chem. Chem. Phys. 2007, 9, 3935-3964. [CrossRef] [PubMed]

29. Lado Ribeiro, A.R.; Moreira, N.F.F.; Li Puma, G.; Silva, A.M.T. Impact of water matrix on the removal of micropollutants by advanced oxidation technologies. Chem. Eng. J. 2019, 363, 155-173. [CrossRef]

30. Zhang, Y.; Wang, B.; Hu, X.; Li, H. Non-activated peroxymonosulfate oxidation of p-aminobenzoic acid in the presence of effluent organic matter. Chem. Eng. J. 2020, 384, 123247. [CrossRef]

31. Mahdi-Ahmed, M.; Chiron, S. Ciprofloxacin oxidation by UV-C activated peroxymonosulfate in wastewater. J. Hazard. Mater. 2014, 265, 41-46. [CrossRef]

32. Arslan-Alaton, I.; Karatas, A.; Pehlivan, Ö.; Koba Ucun, O.; Ölmez-Hanc1, T. Effect of UV-A-assisted iron-based and UV-C-driven oxidation processes on organic matter and antibiotic resistance removal in tertiary treated urban wastewater. Catal. Today 2021, 361, 152-158. [CrossRef]

33. Rodríguez-Chueca, J.; Varella, S.; Rocha, J.; Fernandes, T.; Pablos, C.; Encinas, Á.; Barceló, D.; Rodríguez-mozaz, S.; Manaia, C.M.; Marugán, J. Assessment of full-scale tertiary wastewater treatment by UV-C based-AOPs: Removal or persistence of antibiotics and antibiotic resistance genes? Sci. Total Environ. 2019, 652, 1051-1061. [CrossRef] [PubMed]

34. Rodríguez-Chueca, J.; Garcia-Cañibano, C.; Sarro, M.; Encinas, Á.; Medana, C.; Fabbri, D.; Calza, P.; Marugán, J. Evaluation of transformation products from chemical oxidation of micropollutants in wastewater by photoassisted generation of sulfate radicals. Chemosphere 2019, 226, 509-519. [CrossRef]

35. Michael-Kordatou, I.; Karaolia, P.; Fatta-Kassinos, D. The role of operating parameters and oxidative damage mechanisms of advanced chemical oxidation processes in the combat against antibiotic-resistant bacteria and resistance genes present in urban wastewater. Water Res. 2018, 129, 208-230. [CrossRef] [PubMed]

36. Alaton, I.A.; Karataş, A.Y.; Pehlivan, Ö.; Hanci, T.O. Elimination of antibiotic resistance in treated urban wastewater by iron-based advanced oxidation processes. Desalin. Water Treat. 2019, 172, 235-253. [CrossRef]

37. Hu, Y.; Zhang, T.; Jiang, L.; Yao, S.; Ye, H.; Lin, K.; Cui, C. Removal of sulfonamide antibiotic resistant bacterial and intracellular antibiotic resistance genes by UVC-activated peroxymonosulfate. Chem. Eng. J. 2019, 368, 888-895. [CrossRef]

38. Fiorentino, A.; Esteban, B.; Garrido-Cardenas, J.A.; Kowalska, K.; Rizzo, L.; Aguera, A.; Pérez, J.A.S. Effect of solar photo-Fenton process in raceway pond reactors at neutral $\mathrm{pH}$ on antibiotic resistance determinants in secondary treated urban wastewater. $J$. Hazard. Mater. 2019, 378, 120737. [CrossRef] [PubMed]

39. Narciso-Da-Rocha, C.; Varela, A.R.; Schwartz, T.; Nunes, O.C.; Manaia, C.M. BlaTEM and vanA as indicator genes of antibiotic resistance contamination in a hospital-urban wastewater treatment plant system. J. Glob. Antimicrob. Resist. 2014, 2, 309-315. [CrossRef]

40. Michael, S.G.; Michael-Kordatou, I.; Nahim-Granados, S.; Polo-López, M.I.; Rocha, J.; Martínez-Piernas, A.B.; Fernández-Ibáñez, P.; Agüera, A.; Manaia, C.M.; Fatta-Kassinos, D. Investigating the impact of UV-C/H2O2 and sunlight/H2O2 on the removal of antibiotics, antibiotic resistance determinants and toxicity present in urban wastewater. Chem. Eng. J. 2020, $388,124383$. [CrossRef]

41. Carvalho, I.T.; Santos, L. Antibiotics in the aquatic environments: A review of the European scenario. Environ. Int. 2016, 94, 736-757. [CrossRef]

42. Gillings, M.R.; Gaze, W.H.; Pruden, A.; Smalla, K.; Tiedje, J.M.; Zhu, Y.G. Using the class 1 integron-integrase gene as a proxy for anthropogenic pollution. ISME J. 2015, 9, 1269-1279. [CrossRef] [PubMed]

43. Kampouris, I.D.; Agrawal, S.; Orschler, L.; Cacace, D.; Kunze, S.; Berendonk, T.U.; Klümper, U. Antibiotic resistance gene load and irrigation intensity determine the impact of wastewater irrigation on antimicrobial resistance in the soil microbiome. Water Res. 2021, 193, 116818. [CrossRef]

44. Persoone, G.; Marsalek, B.; Blinova, I.; Törökne, A.; Zarina, D.; Manusadzianas, L.; Nalecz-Jawecki, G.; Tofan, L.; Stepanova, N.; Tothova, L.; et al. A practical and user-friendly toxicity classification system with microbiotests for natural waters and wastewaters. Environ. Toxicol. 2003, 18, 395-402. [CrossRef] [PubMed]

45. Deng, J.; Ge, Y.; Tan, C.; Wang, H.; Li, Q.; Zhou, S.; Zhang, K. Degradation of ciprofloxacin using A-MnO2 activated peroxymonosulfate process: Effect of water constituents, degradation intermediates and toxicity evaluation. Chem. Eng. J. 2017, 330, 1390-1400. [CrossRef]

46. Pentapotassium Bis(peroxymonosulphate)...-Registration Dossier-ECHA. Available online: https://echa.europa.eu/es/ registration-dossier/- / registered-dossier/15990/7/3/1 (accessed on 4 July 2021).

47. A Practical and Low Cost Microbiotest to Assess the Phytotoxic Potential of Growing Media and Soil-WUR. Available online: https: / / www.wur.nl/fr /Publications.htm?publicationId=publication-way-333634343030 (accessed on 4 July 2021).

48. Jaafarzadeh, N.; Ghanbari, F.; Ahmadi, M.; Omidinasab, M. Efficient integrated processes for pulp and paper wastewater treatment and phytotoxicity reduction: Permanganate, electro-Fenton and Co3O4/UV/peroxymonosulfate. Chem. Eng. J. 2017, 308, 142-150. [CrossRef]

49. Moradi, M.; Ghanbari, F. Application of response surface method for coagulation process in leachate treatment as pretreatment for Fenton process: Biodegradability improvement. J. Water Process Eng. 2014, 4, 67-73. [CrossRef]

50. WHO. Sulfate in Drinking-Water Background Document for Development of WHO Guidelines for Drinking-Water Quality; WHO: Geneva, Switzerland, 2004.

51. Water Quality for Agriculture. Available online: http:/ /www.fao.org/3/T0234E/T0234E00.htm (accessed on 4 July 2021). 
52. USEPA. Ultraviolet Light Disinfection Technology in Drinking Water Application-An Overview. Available online: https: / / nepis.epa.gov /Exe/ZyNET.exe/20001SHK.TXT?ZyActionD=ZyDocument\&Client=EPA\&Index=1995+Thru+1999\&Docs= $\&$ Query $=\&$ Time $=\&$ EndTime $=\&$ SearchMethod $=1 \&$ TocRestrict $=$ n\&Toc $=\&$ TocEntry $=\& Q F i e l d=\& Q F i e l d$ Year $=\& Q F i e l d M o n t h=$ $\& Q F i e l d D a y=\& I n t Q F i e l d O p=0 \&$ ExtQFieldOp=0\&XmlQuery $=\& F i l e=D \% 3 A \% 5 C z y f i l e s \% 5 C I n d e x D a t a \% 5$ C 95 thru99 $\% 5 C T x t \%$ 5C00000005\%5C20001SHK.txt\&User=ANONYMOUS\&Password=anonymous\&SortMethod=h\%7C-\&MaximumDocuments= 1\&FuzzyDegree=0\&ImageQuality=r75g8/r75g8/x150y150g16/i425\&Display=hpfr\&DefSeekPage=x\&SearchBack=ZyActionL\& Back=ZyActionS\&BackDesc=Resultspage\&MaximumPages $=1 \& Z y$ Entry=1\&SeekPage=x\&ZyPURL (accessed on 4 July 2021).

53. USEPA. Wastewater Technology Fact Sheet: Ultraviolet Disinfection. Available online: https://www3.epa.gov/npdes/pubs/uv. pdf (accessed on 4 July 2021).

54. Pabi, S.; Reekie, L.; Amarnath, A.; Goldstein, R. Electric Power Research Institute Water Research Foundation Electricity Use and Management in the Municipal Water Supply and Wastewater Industries; EPRI: Palo Alto, CA, USA; Water Research Foundation: Denver, CO, USA, 2013.

55. Bolton, J.R.; Bircher, K.G.; Tumas, W.; Tolman, C.A. Figures-of-merit for the technical development and application of advanced oxidation technologies for both electric-and solar-driven systems. Pure Appl. Chem. 2001, 73, 627-637. [CrossRef] 